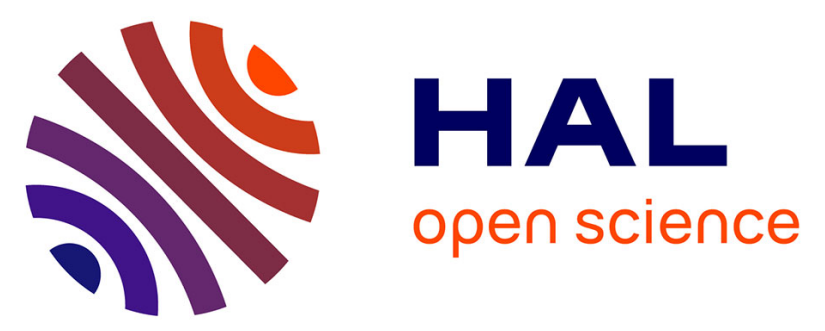

\title{
Phytochemical characteristics of leaves determine foraging rate of the leaf-cutting ant Atta mexicana (Smith) (Hymenoptera: Formicidae)
}

Dennis A Infante-Rodríguez, Juan L Monribot-Villanueva, Klaus Mehltreter, Gloria L Carrión, Jean-Paul Lachaud, A Carlos Velázquez-Narváez, Víctor M Vásquez-Reyes, Jorge E Valenzuela-González, José A Guerrero-Analco

\section{To cite this version:}

Dennis A Infante-Rodríguez, Juan L Monribot-Villanueva, Klaus Mehltreter, Gloria L Carrión, JeanPaul Lachaud, et al.. Phytochemical characteristics of leaves determine foraging rate of the leaf-cutting ant Atta mexicana (Smith) (Hymenoptera: Formicidae). Chemoecology, 2020, 30 (4), pp.147-159. 10.1007/s00049-020-00306-4 . hal-03010499

\section{HAL Id: hal-03010499 \\ https://hal.science/hal-03010499}

Submitted on 24 Nov 2020

HAL is a multi-disciplinary open access archive for the deposit and dissemination of scientific research documents, whether they are published or not. The documents may come from teaching and research institutions in France or abroad, or from public or private research centers.
L'archive ouverte pluridisciplinaire HAL, est destinée au dépôt et à la diffusion de documents scientifiques de niveau recherche, publiés ou non, émanant des établissements d'enseignement et de recherche français ou étrangers, des laboratoires publics ou privés. 


\section{Phytochemical characteristics of leaves determine foraging rate of the leaf-cutting ant Atta mexicana (Smith) (Hymenoptera: Formicidae)}

Dennis A. Infante-Rodríguez ${ }^{1}$, Juan L. Monribot-Villanueva ${ }^{1}$, Klaus Mehltreter ${ }^{1}$, Gloria L. Carrión $^{1}$, Jean-Paul Lachaud ${ }^{2,3}$, A. Carlos Velázquez-Narváez ${ }^{1}$, Víctor M. Vásquez-Reyes ${ }^{1}$, Jorge E. Valenzuela-González ${ }^{1 *}$, José A. Guerrero-Analco ${ }^{1 *}$

${ }^{1}$ Instituto de Ecología, A.C., 91070, Xalapa, Veracruz, Mexico. ${ }^{2}$ El Colegio de la Frontera Sur (Unidad Chetumal), 77014, Chetumal, Quintana Roo, Mexico. ${ }^{3}$ CRCA, Centre de Biologie Intégrative, Université de Toulouse, CNRS, Toulouse Cedex 09, France.

*e-mail: jorge.valenzuela@inecol.mx, joseantonio.guerrero@inecol.mx

ORCID: Infante-Rodriguez D.A. 0000-0002-3330-5340; Guerrero-Analco J.A. 0000-00030998-757X; Valenzuela-González J.E 0000-0003-2106-6693

Abstract -Atta mexicana is a polyphagous insect that can exploit a wide range of plant species to cultivate its main food source, the symbiotic fungus Leucoagaricus gongylophorus. In the present study, we evaluated the foraging rate of Atta mexicana workers among leaves of three favored and three rejected plant species under laboratory conditions. In addition, we conducted a phytochemical characterization of leaves of these six plant species. Ants preferred leaf-discs of Rosa x alba, Trema micrantha and Styrax glabrescens, but rejected those of Coffea arabica, Citrus reticulata and Psidium guajava. In a second behavioral experiment using plant extracts, the results suggest that in the case of $C$. reticulata, rejection was not due chemical composition, but may have been due to different foliar attributes that could modulate the ant's foraging preferences in this species. Alkaloids, phenols, flavonoids, and tannins were present at different concentrations in all six plant species. Furthermore, C. arabica leaves presented significantly higher concentrations of alkaloids and this species, together with $P$. guajava, exhibited the highest concentration of phenols. Rejected plant species showed high concentrations of chlorogenic acid, (-)-epicatechin, quercetin-3, 4-di-O-glucoside (in C. arabica); shikimic acid, ellagic acid and (-)-epicatechin (in P. guajava), and scopoletin (in C. reticulata). Some of the 
28 identified compounds have been shown to possess antifungal effects and/or to dissuade

29 leaf-cutter ants from defoliation. We discuss the likely implications on foraging on such

30 plant species by A. mexicana, and on the growth of its symbiotic fungus.

31 Key Words - Plant-insect interactions, leaf-cutting ants, ant fungal symbiont, plant

32 metabolomics.

33 
35 Leaf-cutting ants are distributed along a wide range of Neotropical habitats, including native and anthropic ecosystems (Cherrett and Peregrine 1976; Vasconcelos and Cherrett 1995; Wirth et al. 1997). They perform an important role in plant defoliation, and are pests in some agricultural and silvicultural plantations (Cherrett 1986; Hölldobler and Wilson 1990; Montoya-Lerma et al. 2012). Workers of leaf-cutting ants forage on leaves, flowers, and fruits of different plant species in order to cultivate their symbiotic fungus Leucoagaricus gongylophorus (Möller) Singer (Weber 1966; Littledyke and Cherrett 1976; Quinlan and Cherrett 1979).

Leaf-cutting ants are considered as generalists due to their adaptability to exploit a wide range of plant species (Littledyke and Cherrett 1976; Quinlan and Cherrett 1979; De Fine Licht and Boomsma 2010). Nevertheless, diverse plant species are foraged at different intensities, and some plants are completely avoided (Howard 1987; Howard et al. 1988). Previous studies suggested that each species of leaf-cutting ants exhibits preferences for particular plants (Cherrett 1972; Rockwood 1976; Hubbell et al. 1984; Hölldober and Wilson 1990), which might be influenced by certain mechanical and chemical characteristics of the foliage (Cherrett 1972; Waller 1982; Berish 1986; Hubbell et al. 1984).

Plant chemical defense strategies include the production of specific secondary/specialized metabolites (Fürstenberg-Hägg et al. 2013). Several groups of secondary metabolites, such as alkaloids (Miyashira et al. 2012), terpenes (Littledyke and Cherrett 1978; Pagnocca et al. 1990; Verza et al. 2011), and phenols (Nichols-Orians 1991) have been reported to be toxic for leaf-cutter ants (Cherrett 1972; Boulogne et al. 2012; Van Bael et al. 2011), or to inhibit the growth and development of their symbiotic fungus (Miyashira et al. 2012; Lobo- 
Echeverri et al. 2016). Indeed, the symbiont fungus of some Atta species have been

59 reported to be able to detoxify certain phenolic compounds present in the leaves of foraged plants (Cherret 1980; Powell and Stradling 1986; Nichols-Orians 1991). In addition, the ant

61 workers obtain certain enzymes (e.g. laccases or polyphenol oxidases) from the fungus;

62 these fungal enzymes pass through the ant gut without being denatured (De Fine Licht et al.

63 2013), are added by the ants through fecal drops placed on the processed plant material

64 (Rockwood 1976). These enzymes help detoxify some compounds present in leaves

65 (Aylward et al. 2013), an ability which ants have lost from their genome (Nygaard et al.

66 2016). Therefore, the range of plants that leaf-cutting ants can harvest appears to have

67 become broader through fungal-derived enzymatic detoxification techniques.

68 Few studies have described the foraging activity of the Mexican leaf-cutting ant Atta

69

70

71

72

73

74

75

76

77

78

79

80 mexicana (Mintzer 1979; Zavala-Hurtado et al. 2000; Mehltreter and Valenzuela 2012), and none of them has associated host plant preferences with the chemical composition of their food plants. Although little studied, the fungal symbiont (hereafter FS) of A. mexicana has been identified as L. gongylophorus based on morphological features and DNA sequencing (Espinoza et al. 2017; Vigueras et al. 2017). The foraging behavior of $A$. mexicana modulated by the occurrence of secondary metabolites (e.g. alkaloids and phenols) in leaves could be expected to be similar to that of other leaf-cutting ant species (as above mentioned).

In this study, we evaluated the effect of secondary metabolites in leaves of different plant species on the foraging behavior of $A$. mexicana. For this, we selected three plant species usually well foraged and three species usually avoided (even when easily accessible) by this ant. Specifically, the study had the following aims: I) to evaluate the foraging rate of 
81 ants on each of the six plant species, II) to determine the total content of alkaloids, phenols,

82 terpenes flavonoids, and, tannins, present in the leaves of these plants, III) to evaluate the

83 effect of leaf extracts on the ant's foraging rate, IV) to test the effect of selected

84 compounds, identified by metabolomic analysis in the leaves of tested plants, on the

85 foraging rate of ants and the growth of symbiotic fungus.

\section{METHODS}

87 Plant Material. In order to verify the foraging preferences of ants we selected young leaves

88 of three species that, according to preliminary observations, were well foraged and three

89 species that were avoided by ants. The first group comprised Trema micrantha (Rosales,

90 Cannabaceae), Styrax glabrescens (Ericales, Styracaceae) and Rosa x alba (Rosales,

91 Rosaceae) [locally named in Spanish as "ixpepe", "azar de monte" and "rosa"], whereas

92 the second group comprised Citrus reticulata (Sapindales, Rutaceae), Coffea arabica

93 (Rubiales, Rubiaceae) and Psidium guajava (Myrtales, Mytaceae) [locally named in

94 Spanish as "mandarina", "cafe" and "guayaba"]. These observations were performed using

95 laboratory-raised colonies of A. mexicana. Young fresh leaves of three different individuals

96 of each plant species were collected in the Botanical Garden of the Instituto de Ecología,

97 A.C., Xalapa, Veracruz, Mexico (19 30' 51.5" N, 96 56' 32.31" W), and from an adjacent

98 fragment of cloud forest.

99 Foraging Rate of Leaf-Cutting Ants. Six experimental sub-colonies without queens that

100 were obtained from six different maternal laboratory-reared colonies were used for this

101 experiment. Each of these sub-colonies (hereafter named experimental units, EU) was built

102 using a plastic jar of $250 \mathrm{~mL}$ containing $10 \mathrm{~g}$ of FS mycelium and included ant larvae,

103 pupae and workers. The plastic jar was connected by a plastic tube to a foraging arena 
consisting of a rectangular plastic container (1.5 L capacity). A water supply was provided by using two glass vials filled with water and plugged with cotton. Before the experiments, sub-colonies were left undisturbed for five days under controlled conditions $\left(25 \pm 1{ }^{\circ} \mathrm{C}\right.$ and $90 \%$ relative humidity). For each plant species, 30 leaf discs of $0.5 \mathrm{~cm}$ in diameter were obtained from three different plants (ten discs from each plant) were offered to each EU in a random order. For each test, the 30 discs of one plant species were placed in each foraging arena. We measured the foraging rate of ants after $24 \mathrm{~h}$ by counting the number of discs that had been taken into the nest ( $c f$. Bruce and Burd 2012). The remaining discs were removed and discarded. After a $2 \mathrm{~h}$ period without access to any leaf discs, a new set of 30 leaf discs from a different plant species were placed in the foraging arena. These experiments were concluded once each EU had been offered leaf material of each plant species. In order to determine the effect of plant species on the foraging rate of leaf-cutting ants, we fitted a Generalized Linear Mixed Model. The number of foraged leaf-discs was considered as the response variable and as predictors the fixed additive effects of offered plant species (treatment), and sub-colony as a random factor. The model was fitted using the linear mixed effect (lme) of the nlme library of R software (R Development Core Team 2008), and the predictor variables were ranked based on the p-value obtained from likelihood ratio tests. Ranked variables were tested using a P value of $<0.05$, as described by Zuur et al. (2009).

Crude Leaf Extracts. Young leaves from three different individuals of each plant species were freeze-dried (LABCONCO FreeZone 1) for 7 days under vacuum at $-56{ }^{\circ} \mathrm{C}$. Dry leaves were pulverized with a porcelain mortar and a pestle, and stored in sealed plastic bags until further use. Crude extracts of leaves were obtained in triplicate samples using an 
127

128

129

130

131

132

133

134

135

136

137

138

139

140

141

142

143

144

145

146

147

148

149

accelerated solvent extraction system (ASE 350, Thermo Scientific, USA), according to a protocol for targeting the extraction of polar and medium polar compounds (Juárez-Trujillo et al. 2017). A mixture of $3 \mathrm{~g}$ of lyophilized leaves from tested individuals $(n=3)$ of each plant species and $1 \mathrm{~g}$ of diatomaceous earth was poured into a $34 \mathrm{~mL}$ glass cell. Each cell was filled with methanol (HPLC grade; Sigma-Aldrich, St. Louis, USA) under a pressure of $1,500 \mathrm{psi}$ and heated at $60{ }^{\circ} \mathrm{C}$ during $5 \mathrm{~min}$. Then, the cells were washed with $30 \%$ of the cell volume. Aliquots of $1 \mathrm{~mL}$ of each sample were placed into a $1.5 \mathrm{~mL}$ centrifuge tube, and formic acid (MS grade; Sigma-Aldrich, St. Louis, USA) was added to obtain a final concentration of $0.1 \%$. Samples were filtered and placed into $1.5 \mathrm{~mL}$ UPLC vials for further analysis using a liquid chromatograph coupled to a mass spectrometer (LC-MS).

The remaining extract of each sample was dried under a fume hood, and this crude extract of leaves was used for the preliminary analyses of total secondary metabolites.

Ant Foraging Rate of Paper-discs Impregnated with Plant Extracts. Six new EU were used for this experiment. Thirty paper discs $(0.5 \mathrm{~cm}$ diameter $)$ impregnated with a solution of 1 $\mathrm{mg} / \mathrm{mL}$ of total crude leaf extract dissolved in methanol were allowed to dry and were then placed in the foraging arena of each sub-colony following previously published procedures (Roses 1990; Bigi et al. 2004). The removal rate of impregnated paper discs by ants after 24 h, was measured by counting the number of discs that had been taken into the nest. The remaining discs were removed and discarded and a new set of 30 paper discs impregnated with extract from a different plant species were offered. This experiment was concluded once each EU had been offered discs impregnated with extracts of each of the plant species. In order to determine the effect of plant species on the foraging rate of leaf-cutting ants, we fitted a General Linear Mixed Model with the number of foraged leaf-discs as the response 
150 variable and as predictors the fixed additive effects of plant species (treatment), and sub-

151 colony as a random factor. The model was fitted using $\mathrm{R}$ software ( $\mathrm{R}$ Development Core

152 Team 2008).

153 Total Content Analyses of Alkaloids, Terpenes Phenols Flavonoids, and, Tannins, .

154 Spectrophotometric methods were applied to the crude extracts of leaves obtained from

155 three individuals per plant species, in order to determine the total content of alkaloids,

156 flavonoids and tannins by using the method of Tambe and Bhambar (2014), and the total

157 phenols following the method of Singleton et al. (1999). The method described by

158 Ferguson (1956) was used as a proxy for the quantification of total terpenes. The resulting

159 values were compared among plant species by one-way ANOVA followed by Tukey's test

160 using R software (R Development Core Team 2008).

161 Chemical Biomarkers Identification by Untargeted Metabolomics Approach. The

162 chromatographic system used for untargeted metabolomics analysis was an Ultra-High

163 Performance Liquid Chromatograph (UPLC) Class I of Waters coupled to a Synapt HDMi

164 mass spectrometer. Chromatography was carried out in an Acquity BEH column (1.7 $\mu$,

$1652.1 \times 50 \mathrm{~mm}$ ) with a column and sample temperatures of $40^{\circ} \mathrm{C}$ and $15^{\circ} \mathrm{C}$, respectively.

166 The mobile phase consisted of (A) water and (B) acetonitrile, both with $0.1 \%$ formic acid

167 (SIGMA). The gradient conditions of the mobile phases were 0-13 min linear gradient 1-

$16880 \%$ of $\mathrm{B}, 13-14$ min isocratic at $80 \%$ of $\mathrm{B}, 14-15$ min linear gradient $80-1 \%$ of $\mathrm{B}, 15-20$

169 min isocratic at $1 \%$ of $\mathrm{B}$. We injected $1 \mu \mathrm{L}$ of sample extracts at a flow rate of $0.3 \mathrm{~mL} / \mathrm{min}$.

170 Mass spectrometric analysis was performed with an electrospray ionization source in

171 positive mode with a capillary, sampling cone and source offset voltages of $3,000 \mathrm{~V}, 40 \mathrm{~V}$

172 and $80 \mathrm{~V}$, respectively. The source temperature was $100^{\circ} \mathrm{C}$ and the desolvation 
173 temperature was $20^{\circ} \mathrm{C}$. The desolvation gas flow was $600 \mathrm{~L} / \mathrm{h}$ and the nebulizer pressure

174 was 6.5 Bar. Leucine-enkephalin was used as the lock mass $\left(556.2771,[\mathrm{M}+\mathrm{H}]^{+}\right)$. The

175 conditions used for MS analysis were: mass range 50-1200 Da, Function $1 \mathrm{CE}, 6 \mathrm{~V}$,

176 function 2 CER $10-30 \mathrm{~V}$, scan time $0.5 \mathrm{sec}$. Data were acquired and processed with

177 MassLynx (version 4.1) and MarkerLynx (version 4.1) software of Waters ${ }^{\mathrm{TM}}$ Corp., in

178 order to identify chemical biomarkers through Principal component analysis (PCA) and

179 Orthogonal Projections to Latent Structures discriminant analysis (OPLS-DA). Retention

180 times and protonated masses were considered at a noise threshold of 10,000 counts, and

181 smoothing was applied. Pareto scaling was applied to generate the score plots. For the S-

182 plots, the variables that contributed to discrimination between two plant species were

183 considered as potential biomarkers.

184

185

186

187

188

189

190

191

192

193

194

195

\section{Identification and Quantification of Individual Phenolic Compounds by Targeted}

Metabolomics Approach. The identification and quantification of individual phenolic compounds was performed with an UPLC Agilent 1290 series coupled to a tandem mass spectrometer (Agilent 6460, triple quadrupole, QqQ) using dynamic multiple reaction monitoring (dMRM) as the acquisition method, following the protocol described by JuárezTrujillo et al. (2017). Chromatographic separations were carried out on a ZORBAX SBC18 column $(1.8 \mu \mathrm{m}, 2.1 \times 50 \mathrm{~mm})($ Agilent Technologies) with a column temperature of 40 ${ }^{\circ} \mathrm{C}$. The mobile phase consisted of (A) water and (B) acetonitrile, both containing $0.1 \%$ formic acid. The gradient conditions for the mobile phase were: $0 \mathrm{~min} 1 \% \mathrm{~B}, 0.1-40 \mathrm{~min}$ linear gradient 1-40\% B, 40.1-42 min linear gradient 40-90\% B, 42.1-44 min isocratic 90\% B isocratic, 44.1-46 min linear gradient $90-1 \% \mathrm{~B}, 46.1-47 \mathrm{~min} 1 \% \mathrm{~B}$ isocratic. The flow rate was $0.1 \mathrm{~mL} / \mathrm{min}$, and the sample injection volume was $5 \mu \mathrm{L}$. The ESI source was 
operated in positive and negative ionization modes at a desolvation temperature of $300{ }^{\circ} \mathrm{C}$, cone gas $\left(\mathrm{N}_{2}\right)$ flow of $5 \mathrm{~L} / \mathrm{min}$, nebulizer pressure at $45 \mathrm{psi}$, sheath gas temperature of 250 ${ }^{\circ} \mathrm{C}$, sheath gas flow of $11 \mathrm{~L} / \mathrm{min}$, capillary voltage (positive and negative) of 3,500 V, and nozzle voltage (positive and negative) of $500 \mathrm{~V}$. For the quantification of each phenolic compound, a calibration curve in a concentration range of 0.3 to $30 \mu \mathrm{M}$ was constructed $\left(\mathrm{R}^{2}\right.$ values $=0.99$ were considered for the linearity range $)$ and quantities were established by using Mass Hunter Workstation Software, version B.06.00 (Agilent Technologies). Values are expressed as $\mu \mathrm{g} / \mathrm{g}$ of sample (dry weight) [see Table S1 for supplementary information].

Ant foraging rate on Leaf-Discs Impregnated with Selected Compounds. Three compounds, identified in leaves of experimental plants by targeted and untargeted metabolomics approaches, were used in their pure form to assess their effect on the foraging rate of ants. Caffeine and chlorogenic acid, both found at high concentrations in C. arabica leaves (a plant rejected by ants), were selected for this test, as well as quercetin because several quercetin derivatives were detected in high concentrations in P. guajava (another rejected plant) and Rosa $\times$ alba (a well foraged plant). For this purpose, five EU from five laboratory ant colonies were set up. Ten leaf-discs of $0.5 \mathrm{~cm}$ in diameter were cut from young leaves of Rosa $x$ alba (the best foraged plant) and impregnated with a $3 \mathrm{mM}$ solution of each selected compound, using distilled water as a solvent. This concentration was chosen based on preliminary experiments performed with the FS in which $3 \mathrm{mM}$ solutions of these compounds showed inhibition of fungal growth (Suppl. Fig. 2). Solutions were mixed by vortex for $2 \mathrm{~min}$ prior to application to leaf discs. Leaf-discs treated only with water alone were used as a solvent control, and dry leaf-discs without water as a foliar 
control. Leaf-discs were offered to ant sub-colonies in a randomized order. After $2 \mathrm{~h}$ of exposure to the ants, the number of removed discs by ants was recorded, and the remaining discs were removed and discarded. To detect treatment effects on foraging rates, we used the non-parametric Kruskal-Wallis test followed by Dunn's post hoc multiple comparison between groups using R software (R Development Core Team 2008).

Assays on the Effect of Selected Compounds on Growth of the Ant-Symbiotic Fungus. Identification of the FS strain was corroborated as Leucoagaricus gongylophorus by using morphological criteria previously described by Espinoza et al. (2017) and Vigueras et al. (2017). Caffeine, chlorogenic acid, and quercetin were tested for this assay of the FS growth. In order to obtain a pure strain of the fungus, serial cultures of $1 \mathrm{mg}$ samples of mycelium obtained from a laboratory-established ant nest were grown on $90 \mathrm{~mm}$ Petri dishes containing $20 \mathrm{~mL}$ of potato-dextrose-agar medium (PDA) and incubated at $25^{\circ} \mathrm{C}$. This fungal strain was used for comparison of the growth rate by using Petri dishes containing five different treatments: PDA (as culture media growth control), PDA mixed with one of each of the three tested compounds (caffeine, chlorogenic acid and quercetin), and PDA plus thiophanate-methyl, a commercial antifungal compound as a growth inhibition control (Holley and Kawchuk 1996). Compounds were tested at 0.03, 0.3 and 3 mM. Each treatment was replicated three times (Suppl. Fig. 2). These concentrations were chosen based on the chlorogenic acid and quercetin concentrations found in the leaves of $C$. arabica $(1692.2 \mu \mathrm{g} / \mathrm{g}$ of fresh tissue) and $P$. guajava (17.9 $\mu \mathrm{g} / \mathrm{g}$ of fresh tissue). Concentrations of 0.03, 0.3 and $3 \mathrm{mM}$ corresponded to $10.2,102.3$ and $1023.0 \mu \mathrm{g} / \mathrm{g}$ of chlorogenic acid in PDA medium, respectively, 8.7, 87.3 and $872.7 \mu \mathrm{g} / \mathrm{g}$ of quercetin in fresh PDA medium, respectively, and 5.6, 56.0 and $560.7 \mu \mathrm{g} / \mathrm{g}$ of caffeine in PDA medium, 
242 respectively. Caffeine was not quantified but it has been reported at a concentration of up to

$2437100 \mu \mathrm{g} / \mathrm{g}$ of fresh tissue (Ashihara et al. 1996). For chlorogenic acid and caffeine, the

244 maximum concentration tested $(3 \mathrm{mM})$ was less than the concentration determined and

245 reported in leaves. For quercetin, the maximum concentration tested $(3 \mathrm{mM})$ was higher

246 than the concentration found in P. guajava leaves.

247 Each treatment was replicated three times. A circle of $1.5 \mathrm{~cm}$ in diameter and $0.5 \mathrm{~cm}$ in

248 height of mycelium previously cultured on PDA was placed in the center of each Petri dish.

249 Mycelium growth, measured as the diameter (in $\mathrm{mm}$ ), was recorded weekly during one

250 month. The percentage of fungal growth inhibition (GI) was calculated using the equation:

$251 \mathrm{GI}=[(\mathrm{DC}-\mathrm{DT}) / \mathrm{DC}] \times 100 ;$ where $\mathrm{DC}$ is the average mycelial diameter of the control

252 treatment, and DT is the individual mycelial diameter. The mean percentage was calculated

253 for each treatment and data were then analyzed by one-way ANOVA and Tukey's test using

254 R software (R Development Core Team 2008).

\section{RESULTS}

256 Ant Foraging Rate of Leaf-discs. The percentage of leaf-discs foraged by the ants (Fig. 1)

257 was significantly influenced by the plant species $\left(\mathrm{F}_{5,25}=13.449 ; \mathrm{P}<0.001\right)$. Variation

258 among EU was not significant $\left(\mathrm{F}_{1,4}=0.245 ; \mathrm{P}=0.6462\right)$. The most preferred species were

259 Rosa x alba, S. glabrescens, and T. micrantha that had 98.8\%, 89.4\% and 54.4\% removal

260 after 24 h, respectively. In contrast, C. arabica, C. reticulata and P. guajava were mostly

261 avoided by the ants with $20.6 \%, 14.4 \%$ and $14.4 \%$ removal respectively, confirming our

262 preliminary field observations. 
Ant Foraging of Paper-discs Impregnated with Plant Extracts. Ant foraging of paper discs was significantly influenced by the plant extract offered $\left(\mathrm{F}_{6,30}=6.733 ; \mathrm{P}<0.01\right)$. Variation among EU was not significant $\left(\mathrm{F}_{1,4}=0.219 ; \mathrm{P}=0.664\right)$. Leaf-cutting ants had a preference for paper-discs impregnated with extracts of Rosa $x$ alba $(35.6 \%$ of disks removed), C. reticulata (32.2\%), T. micrantha (12.8\%) and S. glabrescens $(4.4 \%)$. In addition, in line with the results of the foliar behavior experiment, ant workers rejected paper discs impregnated with extract of $C$. arabica and $P$. guajava with foraging percentages of $1.7 \%$ and $0 \%$, respectively. This suggests that rejection of these species could be due to their chemical composition. Paper discs impregnated with the solvent alone were also avoided (1.1\%) (Fig. 2).

Total Content of Alkaloids, Terpenes, Phenols, Flavonoids and Tannins. The plant species differed significantly in all concentrations of secondary metabolites with the exception of terpenes $\left(\mathrm{F}_{5,12}=0.675, \mathrm{P}>0.05\right.$; Table 1$)$. For $C$. arabica $\left(\mathrm{F}_{5,12}=13.93, \mathrm{P}<0.001\right)$ and $P$. guajava $\left(\mathrm{F}_{5,12}=23.34, \mathrm{P}<0.001\right)$, both species rejected by ants, displayed the highest alkaloid and phenol contents, respectively. C. arabica also had the second highest content of phenols, whereas $C$. reticulata, the other rejected plant species, had an intermediated concentration of phenols and alkaloids, and the lowest content of flavonoids and tannins.

Rosa $\mathrm{x}$ alba, the most preferred plant species, exhibited the lowest concentration of alkaloids and phenols. T. micrantha, presented the second lowest concentration of alkaloids and phenols, whereas $S$. glabrescens, showed the second highest concentration of phenols and the highest concentration of flavonoids and tannins.

Untargeted and Targeted Metabolomics. One of the main aims of this work was to identify key chemical compounds that could explain the ant foraging preferences. To achieve this, 
we used two different metabolomics approaches: untargeted and targeted analyses. The first one was performed to identify the possible presence of groups based on chemical similarities among the plant extracts tested and to correlate them with ant foraging preferences. The ordination of plant species according to their chemical profiles classified them into three groups. S. glabrescens and C. reticulata each represented an individual group, whereas the remaining four species comprised a third group (Fig. 3). The third group contained two rejected and two accepted plant species. In order to identify key compounds we performed two OPLS-DA, first between one accepted (Rosa $x$ alba) and one rejected ( $P$. guajava) plant species (Fig. 4), and the second between two rejected plant species, $P$. guajava and C. arabica (Fig. 5). When the chemical profiles of Rosa $x$ alba and P. guajava were compared, we observed peaks with retention times of 3.8 and $4.1 \mathrm{~min}$ for P. guajava and $4.3 \mathrm{~min}$ for Rosa $\mathrm{x}$ alba as markers, and these peaks were tentatively identified as quercetin derivatives because they share the ion 303.0505 (+/- $5 \mathrm{ppm})$. In a search for this selective ion in the Rosa $x$ alba and $P$. guajava chromatograms, we detected more quercetin derivatives in P. guajava (3.9, 4.0 and $4.2 \mathrm{~min})$. A similar scenario was observed when $C$. arabica and P. guajava chemical profiles were compared (Fig. 5). For P. guajava, we tentatively identified the same chemical markers as in Rosa $x$ alba. In C. arabica, we tentatively identified the alkaloids caffeine and trigonelline, and the phenolic compound mangiferine (Fig. 5).

Most of the chemical markers that were tentatively identified based on the accurate mass spectrometric fingerprints by the untargeted metabolomics approach were phenolic compounds. Consequently, we performed a phenolic targeted metabolomics study in order to confirm the identity and quantity of the putatively phenolic compounds previously 
309

310

311

312

313

314

identified. The targeted metabolomics study was performed with a dynamic multiple reaction monitoring method with 60 phenolic authentic standards. The phenolic compounds identified and quantified by this strategy are shown in Table 2 and the full list of the compounds searched is shown in Supplementary Table 1. A total of 30 compounds were identified and quantified in the leaf methanolic extracts of the six plant species (Table 2), which represented phenolic acids (16), flavonoids (12) and coumarins (2). The most abundant phenolic compounds of the three preferred species were $(+)$-catechin, vanillic acid and quercetin 3-glucoside for S. glabrescens; (+)-catechin for T. micrantha and quercetin 3-D-galactoside, (+)-catechin and quercetin for Rosa $x$ alba. Procyanidin B2 and 3-coumaric acid were only detected in Rosa x alba. The most abundant phenolic compounds of the three rejected plants were chlorogenic acid, (-)-epicatechin, (+)-catechin and some quercetin derivatives in C. arabica, compared to shikimic and ellagic acids, $(+)-$ catechin, quercetin and its derivates in P. guajava. C. reticulata contained mainly rutin, scopolin, ferulic and chlorogenic acids.

Foraging Rate of Leaf-Cutting Ants of Leaf-Discs Impregnated with Pure Compounds. The foraging of leaf-discs of Rosa $x$ alba was negative influenced by impregnation of discs with caffeine, quercetine and chlorogenic acid $[\mathrm{H}(4)=15.417, \mathrm{P}<0.01]$ (Fig. 6).

Growth Inhibition on Ant-Symbiotic Fungus. Fungal growth was significantly affected by the three tested compounds at 28 days $\left(\mathrm{F}_{4,5}=310.4, \mathrm{P}<0.001\right.$; Fig.7). Caffeine had an inhibitory effect on fungal growth across all the tested concentrations $(0.03-3 \mathrm{mM})$, whereas quercetin and chlorogenic acid had a moderated inhibitory effect at $3 \mathrm{mM}$ (Suppl. Fig. 1 and Suppl. Fig. 3). 
333 Leaf-cutting ants are considered to select or to avoid plants (Roces 1990, 1994; Herz et al.

334 2008; Saverscheck et al. 2010; Arenas and Roces 2017). Some plant secondary metabolites

335 fulfill specific ecological defense roles against insects (Rehman et al. 2012; War et al.

336 2012; Pino et al. 2013) or fungi (Bennett and Wallsgrove 1994). High concentrations of

337 certain alkaloids and phenols have plant defensive attributes against herbivores and

338 microorganisms (Villard et al. 2019), and could be involved in the avoidance behavior of $A$.

339 mexicana on two less preferred plants in our foraging tests, because these plants exhibited

340 the highest concentration of alkaloids (C. arabica) and phenols (P. guava), and coffee

341 leaves also showed the second highest concentration of phenols.

342 The main alkaloid produced by $C$. arabica leaves is caffeine, a methylxantine with

343 insecticidal and fungicidal properties (Rizvi et al. 1980; Nathanson 1984; Albuquerque et

344 al. 2009), which has been reported to cause inhibition to the growth of the FS of Atta

345 sexdens (Miyashira et al. 2012). Our results confirmed caffeine as a chemical marker for

346 coffee leaves, and showed that it promotes an avoidance behavior by A. mexicana on the

347 offered rose leaves treated with this compound. We also observed a strong inhibitory effect

348 of caffeine on the growth of the FS of $A$. mexicana.

349 Some phenolic compounds produced by plants have also be implicated in defense against

350 herbivores and pathogens (Rehman et al. 2012; War et al. 2012). One of the most relevant

351 physiological effects of phenols on herbivores is astringency (Ozawa et al. 1987), and some

352 of them possess insecticidal or fungicidal properties (Boulogne et al. 2012). Coffee leaves

353 contained the highest concentrations of three phenolic compounds: chlorogenic acid, (-)-

354 epicatechin, and quercetin 3,4-di-O-glucoside. Chlorogenic acid and (-)-epicatechin exhibit 
355 both fungistatic and fungicidal properties (Martínez et al. 2017; Yamaji and Ichihara 2011,

356 Hirasawa and Takada 2004). In the present study, ants avoided foraging leaf discs of rose

357 impregnated with chlorogenic acid, and this phenolic compound caused a weak inhibition

358 of the mycelial growth of the FS.

359 According to ethnobotanical studies, $P$. guajava is a traditional medicinal plant with a great

360 versatility of uses, including the treatment of fungal infections (Pérez-Gutiérrez et al.

361 2008), and the antifungal effects have been attributed to the presence of phenolic

362 compounds, especially to quercetin and its glycoside derivatives (Metwally et al. 2011;

363 Dakappa et al. 2013; Morais-Braga et al. 2017). Chang et al. (2013) noted that the main

364 components of infusions of $P$. guajava leaves were quercetin, myrcetin, catechin, and gallic

365 and ellagic acids. In addition to these compounds (except myrcetin), we detected 15 other

366 compounds, mainly phenolic acids and flavonoids, and some of them (shikimic, 4-

367 coumaric, and ellagic acids, kaempferol, and kaempferol 3-O-glucoside) were present at

368 high concentrations. Our results revealed quercetin derivatives as chemical markers of

369 guava. Certain glucoside derivatives of quercetin such as quercetin-3-O- $\alpha$-L-rhamnoside

370 have been reported to cause a weak in vitro inhibition in the growth of the FS of $A$. sexdens

371 (Bicalho et al. 2012). Although, quercetin only caused a weak inhibitory effect on the

372 growth of the FS in our assays, in comparison to caffeine, quercetin significantly decreased

373 the removal of rose leaf-discs by ants.

374 Foragers of $A$. mexicana rejected mandarin leaves, while paper discs impregnated with

375 crude extract of this plant were foraged. This suggests that the rejection of C. reticulata

376 leaves was not related to the phytochemical profile obtained from methanol extracts.

377 Mandarin leaves did not contain high concentrations of alkaloids or phenols in comparison 
378 to the remaining tested plants. However, scopoletin was detected in the mandarin extracts,

379 which is a coumarin with antifungal activity (Gnonlonfin et al. 2012; Rehman et al. 2012).

380 In fact, other coumarins inhibit the growth of the FS of Atta sexdens (Godoy et al. 2005).

381 Some other compounds not analyzed in the present study could be responsible for their ant382 repellent effects. For instance, the lipid non-polar fraction from mandarin leaf extracts was

383 reported to repel Acromyrmex octospinosus (Jones et al. 1987), and some of mandarin 384 essential oils showed antifungal properties, likely due to terpenes (Eldahshan 2015). This 385 result suggests that a mixture of attractive and repellent compounds could occur in leaves, 386 and the contrasting effect of this mixture could provoke conflicts to the ant behavior that 387 would explain the sudden changes of foraging preferences reported for Atta species, in 388 which leaves are initially well-harvested and latterly avoided. This behavior, known as 389 delayed rejection, may continue for several months (Knapp et al. 1990, Herz et al. 2008).

390 Despite the relatively high concentrations of some secondary metabolites, the leaf-discs of 391 Rosa $x$ alba and S. glabrescens were well foraged in our foraging experiments. Leaves of 392 Rosa spp. have been previously reported to be well-accepted by leaf-cutting ants (Arenas 393 and Roces 2017; Herz et al. 2008). Although Rosa $x$ alba leaves had the lowest 394 concentrations of alkaloids and phenols, they possessed a remarkable diversity of phenolic 395 acids and flavonoids, with the highest concentrations of protocatechuic, caffeic and ferulic 396 acids. Liu et al. (2013) detected these substances in high concentrations in extracts of the 397 fungus Agaricus bisporus, a genus of the same family as Leucoagaricus; these compounds 398 could have no harmful effects on the FS of $A$. mexicana. However, some other compounds 399 of Rosa spp., such as gallic and salicylic acid, can have antifungal properties (Dixit and 400 Uphadyay 1976). The ant preference for rose leaves and paper discs impregnated with rose 
401

402

403

404

405

406

407

408

409

410

411

412

413

414

415

416

417

418

419

420

421

422

423

extracts suggest a positive response by workers of $A$. mexicana to specific chemical compounds present in the leaves of this plant. Ant workers are exposed to plant juices from cut surfaces of leaves during foraging and preparation of the substrate for the fungus garden (Littledyke and Cherrett 1976). A positive response to this plant could therefore arise though direct ingestion of plant sap and cellular fluids containing these compounds.

Although $S$. glabrescens had the highest concentrations of total flavonoids and tannins, it was well foraged by the ants. The most abundant phenolic compounds identified in the leaves of this plant were vanillic acid, $(+)$-catechin, and quercetin 3-glucoside. These results could be related to the ability of FS to detoxify phenolic compounds, as it has been reported to the FS of other species of leaf-cutting ants (e.g. Cherret 1980; Nygaard et al. 2016). Additionally, some plant phenols play a beneficial role in herbivore insects, especially flavonoids. This includes protection against pathogens and predators (Simmonds 2003), stimulation to either food acceptance or rejection (Schoonhoven and van Loon 2002), phagostimulation (Blaney and Simmonds 1983; Van Drongelen 1979), and increased reproduction (Burghardt et al. 2000).

Interestingly, grouping based on the comprehensive chemical profiles detected by PCA analyses (that summarized the complete dataset, comprising 698 Exact Mass/Retention Time pairs [EMRTs]), suggests a relative similarity among some accepted and rejected plants, remarkably between Rosa x alba (preferred) and P. guajava (rejected).

Nevertheless, differences more detailed in leaf chemical composition detected by the targeted and untargeted metabolomics analyses, the concentration of compounds, and the presence of specific chemical markers (EMRTs with higher levels to $P$. guajava) could explain these differences in the foraging preferences of $A$. mexicana. 
424 Food plant selection of leaf-cutting ants is a complex behavior involving many plant traits, 425 including the composition and concentrations of secondary metabolites. In our study, leaves 426 of two of the less-preferred plants (C. arabica and P. guajava) had higher concentrations of 427 alkaloids and phenolic compounds. In the case of $C$. reticulata leaves (the other not foraged 428 plant), our results suggest that this rejection was due to some additional foliar features.

429 Foragers avoided collecting leaf discs of the most preferred plant (Rosa $x$ alba) after 430 treatment with the three pure tested compounds: caffeine, quercetin and chlorogenic acid.

431 These results suggest that ants are able to perceive the presence of these compounds, which 432 also had a strong or moderate inhibitory effect on the growth of the FS. Several other 433 phenolic compounds identified in leaves of tested plants have been reported to exhibit 434 antifungal properties. In the future, it would be necessary to explore the existence of 435 synergistic or antagonist relationships among these compounds and their effects on the 436 foraging behavior of ants and on the growth of its FS.

437 Overall, our results showed that secondary metabolites play an important role in the process 438 of plant selection by $A$. mexicana. This study represents the first contribution that has 439 investigated simultaneously the possible interrelation between foraging preferences of $A$. 440 mexicana, the phytochemical profiles of their food plants, and the effect of these 441 phytochemical compounds on the FS of $A$. mexicana. In addition, we present the first 442 phytochemical screening for T. micrantha and S. glabrescens, two valuable tropical and 443 subtropical tree species (Quintanar-Isaías et al. 2012, Gonsoulin 1974). 
447 We thank Diana Sánchez Rangel and Randy Ortiz Castro for the access to their laboratory 448 facilities; Dora Luz Martínez Tlapa, Javier Tolome Romero, Ariadna Martínez Virués, 449 Daniela Cela Cadena, Ofelia Ferrera Rodríguez, and José Benjamín Rodríguez Haas for 450 technical assistance at laboratory. We also thank Trevor Williams, Luis Javier Fuentes 451 Jacques and Renato Portela Salomaõ for helpful suggestions and critical comments on the 452 manuscript. Dennis Adrian Infante-Rodríguez acknowledges the fellowship granted by the 453 Consejo Nacional de Ciencia y Tecnología (CVU 409930) and the Doctoral Program of the 454 Instituto de Ecología, A.C. Finally, we thank to the "Secretaría de Agricultura, Ganadería, 455 Desarrollo Rural, Pesca y Alimentación” (SAGARPA) for the financial support to the 456 Laboratory of Natural Products Chemistry, Department of Advanced Molecular Studies of 457 the Instituto de Ecología A.C. (INECOL) for the development of the analytical method by 458 LC-ESI-MS-MS for plant phenolic identification (Project SAGARPA-INECOL 80056). 
461

462

463

464

465

466

467

468

469

470

471

472

473

474

475

476

477

478

479

480

481

482

483

484

485

486

487

488

489

490

491

492

493

494

495

496

497

498

499

500

501

502

503

504

Albuquerque EX, Pereira EF, Alkondon M, Rogers SW (2009) Mammalian nicotinic acetylcholine receptors: from structure to function. Physiol Rev 89:73-120.

doi:10.1152/physrev.00015.2008

Arenas A, Roces F (2017) Avoidance of plants unsuitable for the symbiotic fungus in leafcutting ants: Learning can take place entirely at the colony dump. Plos One 12:e171388. doi:10.1371/journal.pone.0171388

Ashihara H, Monteiro AM, Gillies FM, Crozier A (1996) Biosynthesis of caffeine in leaves of coffee. Plant Physiol 111:747-753. doi:10.1104/pp.111.3.747

Aylward FO, Burnum-Johnson KE, Tringe SG, Teiling C, Tremmel DM, Moeller JA, Scott JJ, Barry KW, Piehowski PD, Nicora CD, Malfatti SA, Monroe ME, Purvine SO, Goodwin LA, Smith RD, Weinstock GM, Gerardo NM, Suen G, Lipton MS, Currie CR (2013) Leucoagaricus gongylophorus produces diverse enzymes for the degradation of recalcitrant plant polymers in leaf-cutter ant fungus gardens. Appl Environ Microbiol 79:3770-3778. doi:10.1128/AEM.03833-12

Bandarra PM, Pavarini SP, Raymundo DL, Corrêa AMR, Pedroso PMO, Driemeier D (2010) Trema micrantha toxicity in horses in Brazil. Equine Vet J 42:456-459.

Berish CW (1986) Leaf-cutting ants (Atta cephalotes) select nitrogen rich forage. Am Midl Nat 115:268-276.

Bennett RN, Wallsgrove RM (1994) Transley Review No.72. Secundary metabolities in plant defence mechanisms. New Phytol 27:617.633.

Bicalho KU, Terezan AP, Martins DC, Freitas TG, Fernandes JB, da Silva MF, Vieira PC, Pagnocca FC, Bueno OC (2012) Evaluation of the toxicity of Virola sebifera crude extracts, fractions and isolated compounds on the nest of leaf-cutting ants. Psyche: ID 785424, 7 p. doi:10.1155/2012/785424

Bigi MFM, Torkomian VL, de Groote ST, Hebling MJA, Bueno OC, Pagnocca FC, Fernandes JB, Vieira PC, da Silva MFG (2004) Activity of Ricinus communis (Euphorbiaceae) and ricinine against the leaf-cutting ant Atta sexdens rubropilosa (Hymenoptera: Formicidae) and the symbiotic fungus Leucoagaricus gongylophorus. Pest Manag Sci 60:933-938. doi:10.1002/ps.892

Blaney WM, Simmonds MSJ (1983) Electrophysiological activity in insects in response to antifeedants. COPR report Project 9, Overseas Development Organisation, London.

Boulogne I, Petit P, Ozier-Lafontaine H, Desfontaines L, Loranger-Merciris G (2012) Insecticidal and antifungal chemicals produced by plants: a review. Environ Chem Lett 10:325-347. doi:10.1007/s10311-012-0359-1 
Bruce AI, Burd M (2012) Allometric scaling of foraging rate with trail dimensions in leafcutting ants. Proc R Soc B 279:2442-2447. doi:10.1098/rspb.2011.2583

Burghardt F, Knüttel H, Becker M, Fiedler K (2000) Flavonoid wing pigments increase attractiveness of female common blue (Polyommatus icarus) butterflies to mate-searching males. Naturwissenschaften 87:304-307.

Chang CH, Hsieh CL, Wang HE, Peng CC, Chyau CC, Peng RY (2013) Unique bioactive polyphenolic profile of guava (Psidium guajava) budding leaf tea is related to plant biochemistry of budding leaves in early dawn. J Sci Food Agric 93:944-954. doi:10.1002/jsfa.5832

Cherrett JM (1972) Some factors involved in the selection of vegetable substrate by Atta cephalotes (L.) (Hymenoptera: Formicidae) in tropical rain forest. J Anim Ecol 41:647660 .

Cherrett JM (1980) Possible reasons for the mutualism between leaf-cutting ants (Hymenoptera: Formicidae) and their fungus. Biol Ecol Méditer 7:113-122.

Cherrett JM (1986) History of the leaf-cutting ant problem. In: Lofgren CS, Vander Meer RK (eds) Fire ants and leaf-cutting ants: biology and management. Westview Press, Boulder.

Cherrett JM, Peregrine DJ (1976) A review of the status of leaf-cutting ants and their control. Ann Appl Biol 84:124-128. doi:10.2307/3200

Dakappa SS, Roshan A, Timilsina SS, Sunita S (2013) A review on the medicinal plant Psidium guajava Linn. (Myrtaceae). J Drug Deliv Ther 3:162-168. doi:10.22270/jddt.v3i2.404

De Fine Licht HH, Boomsma JJ (2010) Forage collection, substrate preparation, and diet composition in fungus-growing ants. Ecol Entomol 35:259-269. doi:10.1111/j.13652311.2010.01193.x

De Fine Licht H, Boomsma J, Tunlid A (2013) Symbiotic adaptations in the fungal cultivar of leaf-cutting ants. Nat Commun 5:5675. doi:10.1038/ncomms6675

Dixit SN, Tripathi SC, Upadhyay R (1976) The antifungal substance of rose flowers (Rosa indica). Econ Bot 30:371-374.

Eldahshan OA (2015) Comparison of chemical and antimicrobial studies of Egyptian mandarin leaves and green branches volatile oil. Eur J Med Plants 5:248-254. doi:10.9734/EJMP/2015/4625

Espinoza C, Zavala Izquierdo I, Couttolenc A, Landa-Cadena G, Valenzuela J, Trigos Á (2017) In vitro isolation and identification of Leucoagaricus gongylophorus from Atta 
590

591

592

593

594

595

596

597

598

mexicana (Hymenoptera: Formicidae) fungal garden. Revista Mexicana de Micología $46: 3-8$.

Ferguson NM (1956) A textbook of pharmacognosy. Macmillan Co., New Delhi.

Fürstenberg-Hägg J, Zagrobelny M, Bak S (2013) Plant defense against insect herbivores. Int J Mol Sci 14:10242-10297. doi:10.3390/ijms140510242

Godoy MFP, Victor SR, Bellini AM, Guerreiro G, Rocha WC, Bueno OC, Hebling MJA, Bacci Jr M, da Silva MFGF, Vieira PC, Fernandes JB, Pagnocca FC (2005) Inhibition of the symbiotic fungus of leaf-cutting ants by coumarins. J Braz Chem Soc 16:669-672. doi:10.1590/S0103-50532005000400031

Gonsoulin GJ (1974) A revision of Styrax (Styracaceae) in North America, Central America, and the Caribbean. Sida 5(4):191-258.

Gnonlonfin GJB, Sanni A, Brimer L (2012) Review scopoletin - A coumarin phytoalexin with medicinal properties. Crit Rev Plant Sci. doi: 10.1080/07352689.2011.616039

Herz H, Hölldobler B, Roces F (2008) Delayed rejection in a leaf-cutting ant after foraging on plants unsuitable for the symbiotic fungus. Behavior Ecol 19:575-582. doi:10.1093/beheco/arn016

Hirasawa M, Takada K (2004) Multiple effects of green tea catechin on the antifungal activity of antymicotics agains Candida albicans. J Antimicrob Chemother 53:225-229.

Holley JD, Kawchuk LM (1996) Distribution of thiabendazole and thiophanate-methyl resistant strains of Helminthosporum solani and Fusarium sambucinum in Alberta potato storages. Can Plant Disease Surv 76(1):21-27.

Hölldobler B, Wilson EO (1990) The ants. Harvard University, Cambridge.

Howard JJ (1987) Leafcutting ant diet selection: the role of nutrients, water, and secondary chemistry. Ecology 68:503-515. doi:10.2307/1938455

Howard JJ, Cazin Jr J, Wiemer DF (1988) Toxicity of terpenoid deterrents to the leaf-cutting ant Atta cephalotes and its mutualistic fungus. J Chem Ecol 14:59-69. doi:10.1007/BF0102253

Hubbell SP, Howard JJ, Wiemer DF (1984) Chemical leaf repellency to an attine ant: seasonal distribution among potential host plant species. Ecology 65:1067-1076. doi: $10.2307 / 1938314$

Jones V, Pollard GV, Seaforth CE (1987) Chemical deterrency of Citrus reticulata (Blanco) to the leaf-cutting ant, Acromyrmex octospinosus (Reich). Insect Sci Applic 8:99-102. doi: $10.1017 / \mathrm{S} 1742758400007050$ 
599

600

601

602

603

604

605

606

607

608

609

610

611

612

613

614

615

616

617

618

619

620

621

622

623

624

625

626

627

628

629

630

631

632

633

634

635

636

637

638

639

640

641

642

643

644

645

Juárez-Trujillo N, Jiménez Fernández VM, Guerrero Analco JA, Monribot Villanueva JL, Jiménez Fernandez M (2017) Caracterización del aceite y harina obtenido de la semilla de uva silvestre (Vitis tiliifolia). Rev Mex Cien Agríc 8:1113-1126.

Knapp JJ, Howse PE, Kermarrec A (1990) Factors controlling foraging patterns in the leafcutting ant Acromyrmex octospinosus (Reich). In: Vander Meer,RK, Jaffé K. (eds), Applied Myrmecology: a World Perspective. Westview Press, Boulder.

Littledyke M, Cherrett JM (1976) Direct ingestion of plant sap from cut leaves by the leafcutting ants Atta cephalotes (L.) and Acromyrmex octospinosus (Reich) (Formicidae, Attini). Bull Ent Res 66:205-217. doi:10.1017/S0007485300006647

Littledyke M, Cherrett JM (1978) Olfactory responses of the leaf-cutting ants Atta cephalotes (L.) and Acromyrmex octospinosus (Reich) (Hymenoptera: Formicidae) in the laboratory. Bull Entomol Res, 68(2):273. doi:10.1017/s0007485300007355

Liu J, Jia L, Kan J, Jin CH (2013) In vitro and in vivo antioxidant activity of ethanolic extract of white button mushroom (Agaricus bisporus). Food Chem Toxicol 51:310-316. doi:10.1016/j.fct.2012.10.014

Lobo-Echeverri T, Salazar LC, Hernández A, Ortiz-Reyez A (2016). Effects of Capsicum baccatum and $C$. frutescens against Atta cephalotes (Hymenoptera: Formicidae) and the symbiotic fungus Leucoagaricus gongylophorus. Rev Colomb Entomol 42:137-145.

Lorenzett MP, Pereira PR, Bassuino DM, Konradt G, Panziera W, Bianchi MV, Argenta FF, Hammerschmitt ME, Caprioli RA, De Barros CSL, Pavarini SP, Driemeier D (2018) Neurotoxicosis in horses associated with consuption of Trema micrantha. Equine Vet $\mathbf{J}$ 50:192-195. doi:10.1111/evj.12741

Martínez G, Regente M, Jacobi S, Del Rio M, Pinedo M, de la Canal L (2017) Chlorogenic acid is a fungicide active against phytopathogenic fungi. Pest Biochem Physiol 140:30-35. doi:10.1016/j.pestbp.2017.05.012

Mehltreter K, Valenzuela J (2012) Leafcutter ants as test organisms for leaf quality of ferns. Indian Fern J 29:262-268.

Metwally AM, Omar AA, Ghazy NM, Harraz FM, El Sohafy SM (2011) Monograph of Psidium guajava L. leaves. Pharmacog J 3:89-104. doi:10.5530/pj.2011.21.17

Mintzer A (1979) Foraging activity of the Mexican leafcutting ant Atta mexicana (F. Smith), in a Sonoran desert habitat (Hymenoptera, Formicidae). Insect Soc 26:364-372.

doi:10.1007/BF02223555

Miyashira CH, Tanigushi DG, Gugliotta AM, Santos DYAC (2012) Influence of caffeine on the survival of leaf-cutting ants Atta sexdens rubropilosa and in vitro growth of their mutualistic fungus. Pest Manag Sci 68:935-940. doi:10.1002/ps.3254 
666

667

668

669

670

671

672

673

674

675

676

677

678

679

680

681

682

683

684

685

686

687

688

689

690

691

Montoya-Lerma J, Giraldo-Echeverri C, Armbrecht I, Farji-Brener A, Calle Z (2012) Leafcutting ants revisited: Towards rational management and control. Int J Pest Manag 58:225-247. doi:10.1080/09670874.2012.663946

Morais-Braga MFB, Carneiro JNP, Machado AJT, Sales DL, dos Santos ATL, Boligon AA, Athayde ML, Menezes IRA, Souza DSL, Costa JGM, Coutinho HDM (2017) Phenolic composition and medicinal usage of Psidium guajava Linn.: Antifungal activity or inhibition of virulence? Saudi J Biol Sci 24:302-313. doi:10.1016/j.sjbs.2015.09.028

Nathanson JA (1984) Caffeine and related methylxanthines: possible naturally occurring pesticides. Science 226:184-187. doi:10.1126/science.6207592

Nichols-Orians CM (1991) Condensed tannins, attine ants, and the performance of a symbiotic fungus. J Chem Ecol 17:1177-1195.

Nygaard S, Hu H, Li C, Schiøtt M, Chen Z, Yang Z, Xie Q, Ma C, Deng, Y, Dikow R, Rabeling C, Nash D, Brady S, Schultz TR, Zhang G, Boomsma JJ (2016). Reciprocal genomic evolution in the ant-fungus agricultural symbiosis. Nat Commun 7: 12233. doi: $10.1038 /$ ncomms 12233

OzawaT, Lilley TH, Haslam E (1987) Polyphenol interactions: astringency and the loss of astringency of ripening fruit. Phytochemistry 26:2937-2942. doi:10.1016/S00319422(00)84566-5

Pagnocca FC, da Silva OA, Hebling-Beraldo MJ, Bueno OC, Fernandes JB, Vieira PC (1990) Toxicity of sesame extracts to the symbiont fungus of leaf-cutting ants. Bull Entomol Res 80:349-352. doi:10.1017/S0007485300050550

Pérez-Gutiérrez RM, Mitchell S, Vargas Solis R (2008) Psidium guajava: A review of its traditional uses, phytochemistry and pharmacology. J Ethnopharmacol 117:1-27.

Pino O, Sánchez Y, Rojas MM (2013) Plant secondary metabolites as an alternative in pest management. I: Background, research approaches and trends. Rev Protección Veg 28 (2):81-94.

Powell RJ, Stradling DJ (1986) Factors influencing the growth of Attamyces bromatificus, a symbiont of attine ants. Trans Br Mycol Soc 87:205-213. doi:10.1016/S0007$1536(86) 80022-5$

Quinlan RJ, Cherrett JM (1979) The role of fungus in the diet of the leaf-cutting ant Atta cephalotes (L.). Ecol Entomol 4:151-160. doi:10.1111/j.1365-2311.1979.tb00570.x

Quintanar-Isaías A, Jacobo-Villa MA, López-Binnqüist C, Flores-Hernández N, JaramilloPérez AT, Pérez-Olvera CP (2012) La madera de Trema micrantha (L.) Blume de Veracruz, México. Madera Bosq 18(2):73-91. doi:10.21829/myb.2012.182353 
692

R Development Core Team (2008) R: A language and environment for statistical computing. R Foundation for Statistical Computing, Vienna, Austria. ISBN: 3-900051-07-0, URL: http://www.R-project.org

Rehman F, Khan F, Badruddin S (2012) Role of phenolics in plant defense against insect herbivory. In: Khemani L, Srivastava M, Srivastava S (eds) Chemistry of Phytopotentials: Health, Energy and Environmental Perspectives. Springer, Berlin.

Rizvi SJH, Jaiswal V, Mukerji D, Mathur SN (1980) Antifungal properties of 1,3,7trimethylxanthine, isolated from Coffea arabica. Naturwissenschaften 67:459-460. doi:10.1007/BF00405645

Roces F (1990) Olfactory conditioning during the recruitment process in a leaf-cutting ant. Oecologia 83:261-262. doi:10.1007/BF00317762

Roces F (1994) Odour learning and decision-making during food collection in the leafcutting ant Acromyrmex lundi. Insect Soc 41:235-239. doi:10.1007/BF01242294

Rockwood LL (1976) Plant selection and foraging patterns in two species of leaf-cutting ants (Atta). Ecology 57:48-61. doi:10.2307/1936397

Saverschek N, Herz H, Wagner M, Roces F (2010) Avoiding plants unsuitable for the symbiotic fungus: learning and long-term memory in leaf-cutting ants. Anim Behav 79:689-698. doi:10.1016/j.anbehav.2009.12.021

Schoonhoven LM, van Loon JJA (2002) An inventory of taste in caterpillars: each species its own key. Acta Zool Acta Sci H 48:215-263.

Simmonds MSJ (2003) Flavonoid-insect interactions: recent advances in our knowledge. Phytochemistry 64:21-30. doi:10.1016/s0031-9422(03)00293-0

Singleton VL, Orthofer R, Lamuela-Raventós RM (1999) Analysis of total phenols and other oxidation substrates and antioxidants by means of folin-ciocalteu reagent. Meth Enzymol 299:152-178. doi:10.1016/S0076-6879(99)99017-1

Tambe V, Bhambar R (2014) Phytochemical screening and anthelmintic activity of wood and leaves of Hibiscus tiliaceus Linn. World J Pharm Pharm Sci 3:880-889.

Van Bael SA, Estrada C, Wcislo WT (2011) Fungal-fungal interactions in leaf-cutting ant agriculture. Psyche: article ID 617478, 9 p. doi: 10.1155/2011/617478

Van Drongelen W (1979) Contact chemoreception of host plant specific chemicals in larvae of various Yponomenta species (Lepidoptera). J Comp Physiol 134:265-279.

Vasconcelos HL, Cherrett JM (1995) Changes in leaf-cutting ant populations (Formicidae: Attini) after the clearing of mature forest in Brazilian Amazonia. Stud Neotrop Fauna Environ 30:107-113. 
Verza SS, Nagamoto NS, Forti LC, Noronha Jr NC (2011) Preliminary studies on the effects of $d$-limonene to workers of the leaf-cutting ant Atta sexdens rubropilosa and its implications for control. Bull Insectol 64:27-32. doi:10.1080/01650529509360947

Vigueras G, Paredes-Hernández D, Revah S, Valenzuela J, Olivares-Hernández R, Le Borgne S (2017) Growth and enzymatic activity of Leucoagaricus gongylophorus, a mutualistic fungus isolated from the leaf-cutting ant Atta mexicana, on cellulose and lignocellulosic biomass. Letts Appl Microbiol 65(2):173-181. doi:10.1111/lam.12759

Villard C, Larbat R, Munakata R, Hehn A (2019) Defence mechanisms of Ficus: pyramiding strategies to cope with pests and pathogens. Planta 249:617. doi:10.1007/s00425-019-03098-2

Waller DA (1982) Leaf-cutting ants and live oak: The role of leaf toughness in seasonal and intraspecific host choice. Entomol Exp Appl 32:146-150. doi:10.1111/j.15707458.1982.tb03195.x

War AR, Paulraj MG, Ahmad T, Buhroo AA, Hussain B, Ignacimuthu S, Sharma HC (2012) Mechanisms of plant defense against insect herbivores. Plant Signaling and Behavior 7:1306-1320. doi:10.4161/psb.21663

Weber NA (1966) Fungus-growing ants. Science 153: 87-604. doi:10.1126/science.153.3736.587

Wirth R, Beyschlag W, Ryel RJ, Hölldobler B (1997) Annual foraging of the leaf-cutting ant Atta colombica in a semideciduous rain forest in Panama. J Trop Ecol 13:741-757. doi:10.1017/S0266467400010907

Yamaji K, Ichihara Y (2011) The role of catechin and epichatechin in chemical defense against damping-off fungi of current-year Fagus crenata seedlings in natural forest. For Path 42:1-7. doi.org/10.1111/j.1439-0329.2010.00709.x

Zavala-Hurtado JA, Valverde PL, Herrera-Fuentes MC, Díaz-Solís A (2000) Influence of leaf-cutting ants (Atta mexicana) on performance and dispersion patterns of perennial desert shrubs in an inter-tropical region of Central Mexico. J Arid Environ 46:93-102. doi:10.1006/jare.2000.0655

Zuur AF, Ieno EN, Walker NJ, Saveliev AA, Smith GM (2009) Mixed effects models and extensions in ecology with R. Springer, New York. 
Table 1 . Total content of secondary metabolites $[\mathrm{mg} / \mathrm{g}]$ in plant species rejected or accepted by the leaf-cutter ant $A$. mexicana.

\begin{tabular}{|c|c|c|c|c|c|}
\hline Plant species & Alkaloids ${ }^{1}$ & Terpenes & Phenols ${ }^{2}$ & Flavonoids $^{3}$ & Tannins $^{2}$ \\
\hline \multicolumn{6}{|l|}{ Rejected } \\
\hline C. arabica & $5.4 \pm 1.76^{\mathrm{a}}$ & $10.2 \pm 2.05^{\mathrm{a}}$ & $81.1 \pm 0.02^{b}$ & $24.6 \pm 6.12^{c}$ & $2.6 \pm 0.05^{\mathrm{e}}$ \\
\hline C. reticulata & $0.8 \pm 0.41^{b}$ & $8.5 \pm 2.53^{\mathrm{a}}$ & $42.8 \pm 19.90^{\mathrm{bc}}$ & $2.5 \pm 0.32^{\mathrm{d}}$ & $0.3 \pm 0.01^{\mathrm{f}}$ \\
\hline P. guajava & $0.8 \pm 0.78^{b}$ & $9.2 \pm 1.03^{\mathrm{a}}$ & $145.1 \pm 16^{a}$ & $32.3 \pm 4.44^{\mathrm{bc}}$ & $17.6 \pm 1.7^{\mathrm{b}}$ \\
\hline \multicolumn{6}{|l|}{ Accepted } \\
\hline S. glabrescens & $1.9 \pm 0.82^{\mathrm{b}}$ & $11.6 \pm 4.51^{\mathrm{a}}$ & $46.8 \pm 2.36^{b c}$ & $48.7 \pm 7.50^{a}$ & $25.7 \pm 0.51^{\mathrm{a}}$ \\
\hline T. micrantha & $0.8 \pm 0.22^{b}$ & $11.3 \pm 1.71^{\mathrm{a}}$ & $32.5 \pm 14.72^{c}$ & $23.4 \pm 2.80^{\mathrm{c}}$ & $4.5 \pm 0.05^{\mathrm{d}}$ \\
\hline Rosa $x$ alba & $0.4 \pm 0.06^{\mathrm{b}}$ & $10.2 \pm 1.63^{\mathrm{a}}$ & $17.7 \pm 4.93^{\mathrm{c}}$ & $40.7 \pm 8.41^{\mathrm{ab}}$ & $13.7 \pm 0.40^{\mathrm{c}}$ \\
\hline
\end{tabular}

Total content of SM [average $(n=3) \pm$ SD]. Different letters indicate significant differences among species (Tukey's test, $\mathrm{P}<0.05$ ). Numeric superindexes refer to chemical equivalents of: berberine (1), gallic acid (2), and quercetin (3). 
Table 2. Phenolic compounds $(\mu \mathrm{g} / \mathrm{g})$ of methanolic extracts of three rejected and three preferred food plant species of $A$. mexicana. Different letters indicate significant differences among metabolites for each species (Tukey's test, $\mathrm{P}<0.05)$ [average $(\mathrm{n}=3) \pm$ SD].

\section{Rejected plant species}

\begin{tabular}{|c|c|c|c|c|c|c|}
\hline \multirow[b]{2}{*}{ Compound } & \multicolumn{3}{|c|}{ Rejected plant species } & \multicolumn{3}{|c|}{ Preferred plant species } \\
\hline & C. arabica & $\begin{array}{c}C . \\
\text { reticulata }\end{array}$ & P. guajava & $\begin{array}{c}\text { S. } \\
\text { glabrescens }\end{array}$ & $\begin{array}{c}T . \\
\text { micrantha }\end{array}$ & Rosa $\times$ alba \\
\hline Shikimic acid & - & - & $\begin{array}{l}229 \pm \\
59.1^{\mathrm{abc}}\end{array}$ & - & - & $154.44 \pm 43.1^{b c}$ \\
\hline Gallic acid & - & - & $\begin{array}{l}136 \pm \\
35.6^{\mathrm{bc}}\end{array}$ & - & - & $110.87 \pm 42.93^{c}$ \\
\hline Protocatechuic acid & - & - & $\begin{array}{l}40.3 \pm \\
12.3^{\mathrm{c}}\end{array}$ & - & - & $42.85 \pm 29.86^{\mathrm{c}}$ \\
\hline Procyanidin B2 & - & - & - & - & - & $458.24 \pm 295.56 \mathrm{ab}$ \\
\hline Gentisic acid & - & - & $\begin{array}{l}39.1 \pm \\
20.4^{c}\end{array}$ & - & - & $20.95 \pm 8.53^{c}$ \\
\hline Chlorogenic acid & $\begin{array}{c}24875 \pm \\
1560^{\mathrm{a}}\end{array}$ & $11.8 \pm 4.0^{\mathrm{b}}$ & $\begin{array}{l}125.8 \pm \\
47.0^{\mathrm{bc}}\end{array}$ & - & $2.5 \pm 0.3^{\mathrm{b}}$ & $91.66 \pm 14.69^{\mathrm{c}}$ \\
\hline Caffeic acid & $1.8 \pm 0.1^{\mathrm{c}}$ & $2.6 \pm 0.9^{b}$ & $41.9 \pm 7.0^{c}$ & - & $1.9 \pm 0.2^{b}$ & $103.53 \pm 34.15^{\mathrm{c}}$ \\
\hline $\begin{array}{l}\text { 4-Hydroxybenzoic } \\
\text { acid }\end{array}$ & $5.2 \pm 2.7^{\mathrm{c}}$ & $0.1 \pm 0.1^{\mathrm{b}}$ & - & - & - & - \\
\hline Vanillin & - & $0.9 \pm 0.2^{\mathrm{b}}$ & $\begin{array}{l}25.82 \pm \\
5.53^{\mathrm{c}}\end{array}$ & $1.19 \pm 1.5^{\mathrm{b}}$ & - & $86.09 \pm 4.3^{\mathrm{c}}$ \\
\hline Vanillic acid & $0.7 \pm 0.1^{\mathrm{c}}$ & - & $11.9 \pm 1.3^{\mathrm{c}}$ & & $0.8 \pm 0.1 * \mathrm{~b}$ & - \\
\hline 3-Coumaric acid & - & - & - & - & - & $78.77 \pm 18.81 \mathrm{c}$ \\
\hline 4-Coumaric acid & $0.1 \pm 0.01^{\mathrm{c}}$ & $2.6 \pm 0.4^{b}$ & $\begin{array}{l}257 \pm \\
115^{\text {abc }}\end{array}$ & - & $2.3 \pm 0.2^{b}$ & $153.34 \pm 53.27^{\mathrm{bc}}$ \\
\hline $\begin{array}{c}\text { Trans-Cinnamic } \\
\text { acid }\end{array}$ & $7.57 \pm 0.26^{\mathrm{c}}$ & $4.6 \pm 1.01^{\mathrm{b}}$ & $36.7 \pm 10.7^{\mathrm{c}}$ & - & $\begin{array}{c}11.04 \pm \\
1.25^{\mathrm{b}}\end{array}$ & $48.46 \pm 29.1^{\mathrm{c}}$ \\
\hline Ferulic acid & - & $16.3 \pm 3.2^{\mathrm{b}}$ & $11.4 \pm 1.5^{\mathrm{c}}$ & $3.07 \pm 5.32^{\mathrm{b}}$ & - & $33.71 \pm 13.86^{\mathrm{c}}$ \\
\hline Ellagic acid & - & - & $\begin{array}{l}267 \pm \\
16.5^{\mathrm{abc}}\end{array}$ & - & - & $105.84 \pm 40.09^{c}$ \\
\hline
\end{tabular}


* Values below the limit of quantification. Average $(\mathrm{n}=3)$ concentration $\pm \mathrm{SD}$ in $\mu \mathrm{g} / \mathrm{g}$

Table 2. (Continued).

Rejected plant species

\begin{tabular}{|c|c|c|c|c|c|c|}
\hline \multirow[b]{2}{*}{ Compound } & \multicolumn{3}{|c|}{ Rejected plant species } & \multicolumn{3}{|c|}{ Preferred plant species } \\
\hline & C. arabica & $\begin{array}{c}C . \\
\text { reticulata }\end{array}$ & P. guajava & S. glabrescens & $\begin{array}{c}T . \\
\text { micrantha }\end{array}$ & Rosa $\times$ alba \\
\hline (-)-Epicatechin & $\begin{array}{l}13129 \pm \\
1876^{\mathrm{b}}\end{array}$ & - & $158 \pm 57.7^{\mathrm{bc}}$ & $0.22 \pm 0.08 * \mathrm{~b}$ & $\begin{array}{l}45.09 \pm \\
25.64 \mathrm{~b}\end{array}$ & $138.21 \pm 123.9^{\mathrm{bc}}$ \\
\hline$(+)$-Catechin & $260 \pm 40^{\mathrm{c}}$ & - & $\begin{array}{l}97.83 \pm \\
31.41^{\mathrm{bc}}\end{array}$ & $754.93 \pm 306.57^{\mathrm{a}}$ & $\begin{array}{l}2881 \pm \\
530.65^{\mathrm{a}}\end{array}$ & $322.91 \pm 202.97^{\mathrm{bc}}$ \\
\hline $\begin{array}{l}\text { Quercetin 3,4-di- } \\
\text { O-glucoside }\end{array}$ & $\begin{array}{c}592.5 \pm \\
21.7^{\mathrm{c}}\end{array}$ & - & $123 \pm 9.4^{\mathrm{bc}}$ & - & - & - \\
\hline Rutin & $\begin{array}{c}286.3 \pm \\
151^{\mathrm{c}}\end{array}$ & $\begin{array}{l}66.8 \pm \\
31.3^{\mathrm{a}}\end{array}$ & - & - & - & $272.42 \pm 45.35^{\mathrm{bc}}$ \\
\hline $\begin{array}{l}\text { Quercetin 3-D- } \\
\text { galactoside }\end{array}$ & $\begin{array}{l}57.3 \pm \\
45.2^{\mathrm{c}}\end{array}$ & - & $479 \pm 195^{a}$ & $6.84 \pm 0.01^{\mathrm{b}}$ & $16.4 \pm 7.27^{b}$ & $771.99 \pm 268.79^{\mathrm{a}}$ \\
\hline $\begin{array}{l}\text { Quercetin 3- } \\
\text { glucoside }\end{array}$ & $\begin{array}{c}221.8^{ \pm} \\
36.8^{\mathrm{c}}\end{array}$ & - & $186 \pm 32^{\mathrm{bc}}$ & $12.09 \pm 13.81^{\mathrm{b}}$ & $22.5 \pm 2.8^{\mathrm{b}}$ & $179.54 \pm 50.41^{\mathrm{bc}}$ \\
\hline Kaempferol & - & - & $348 \pm 211^{\mathrm{ab}}$ & - & - & $31.55 \pm 7.05^{\mathrm{c}}$ \\
\hline $\begin{array}{l}\text { Kaempferol 3-O- } \\
\text { glucoside }\end{array}$ & $12.0 \pm 0.8^{\mathrm{c}}$ & - & $233 \pm 125^{\mathrm{abc}}$ & $5.72 \pm 9.9^{b}$ & $37.3 \pm 13.2^{\mathrm{b}}$ & $26.75 \pm 3.49^{c}$ \\
\hline $\begin{array}{l}\text { Luteolin 7-O- } \\
\text { glucoside }\end{array}$ & - & $5.7 \pm 0.1^{\mathrm{b}}$ & - & - & $7.1 \pm 1.0^{\mathrm{b}}$ & - \\
\hline Luteolin & - & $2.3 \pm 0.1^{\mathrm{b}}$ & - & - & $3.4 \pm 0.2^{\mathrm{b}}$ & - \\
\hline Myricetin & - & - & $79.14 \pm 23.08 \mathrm{c}$ & - & - & - \\
\hline
\end{tabular}

Preferred plant species 
Scopolin

Umbelliferone

* Values below the limit of quantification 


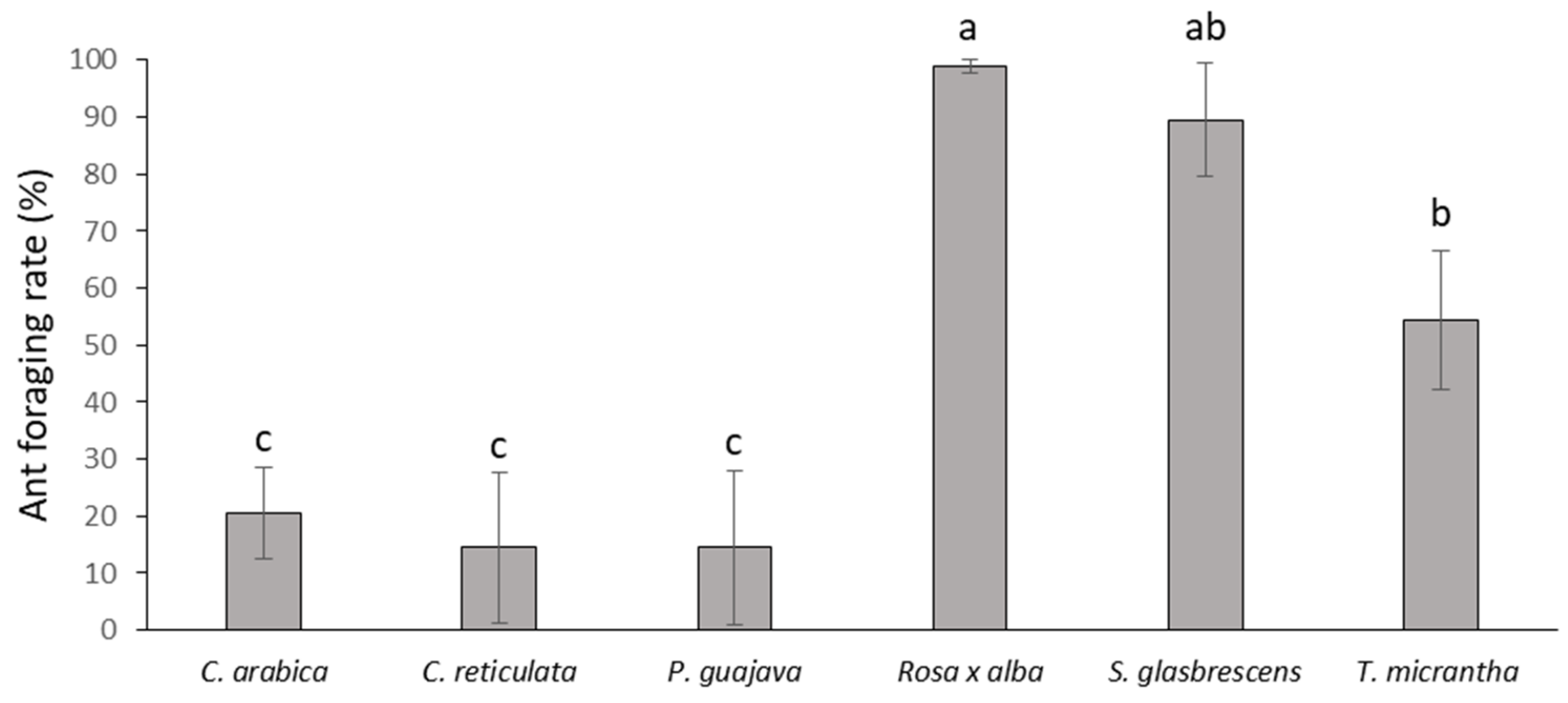




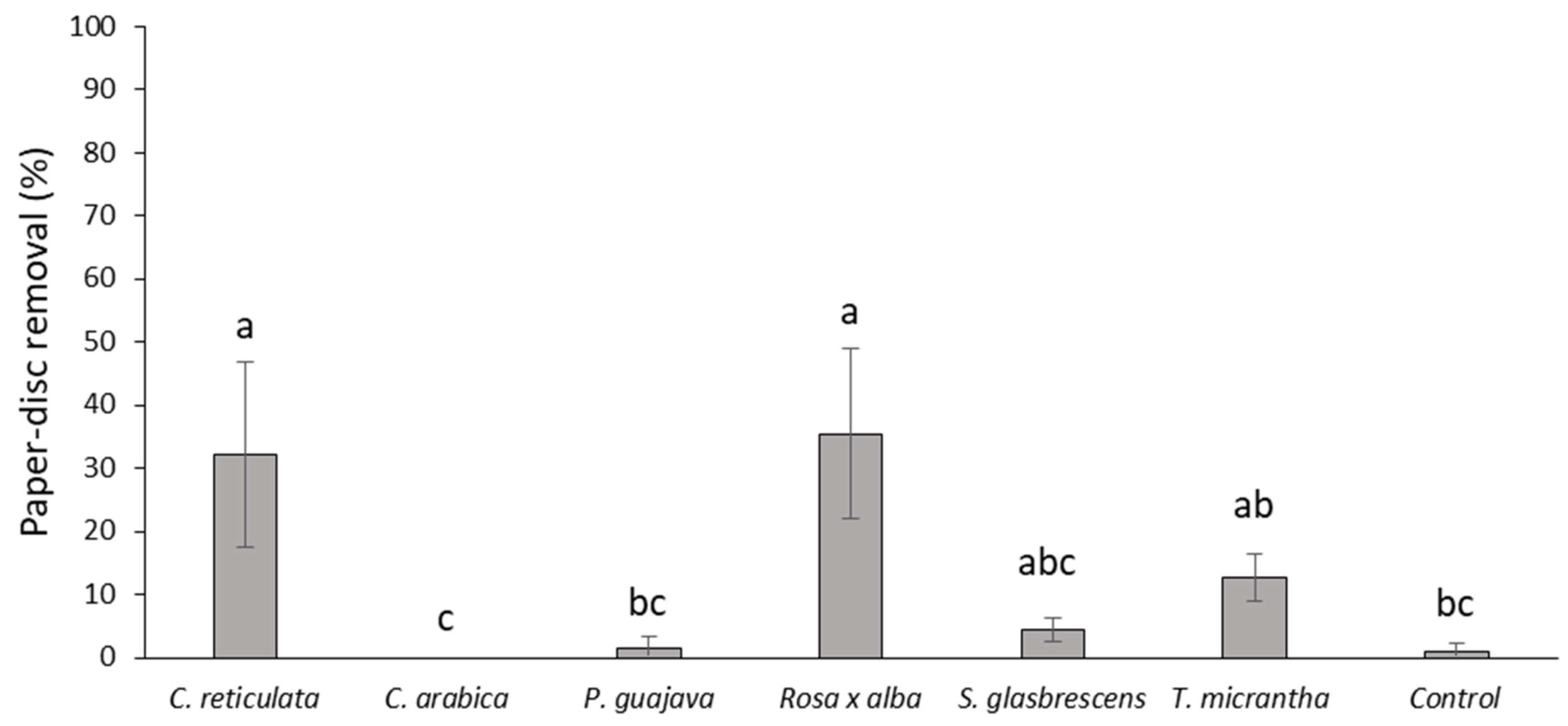




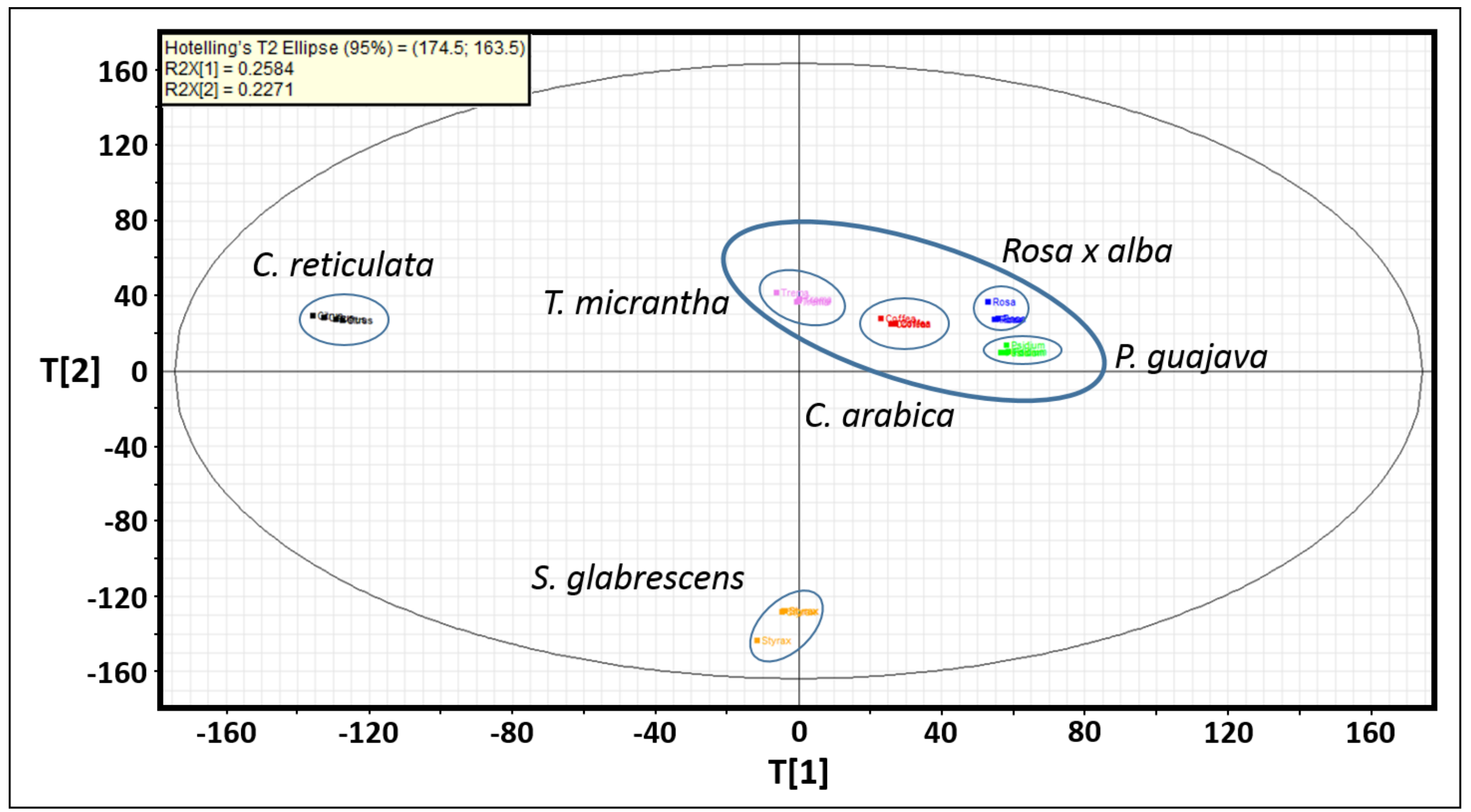




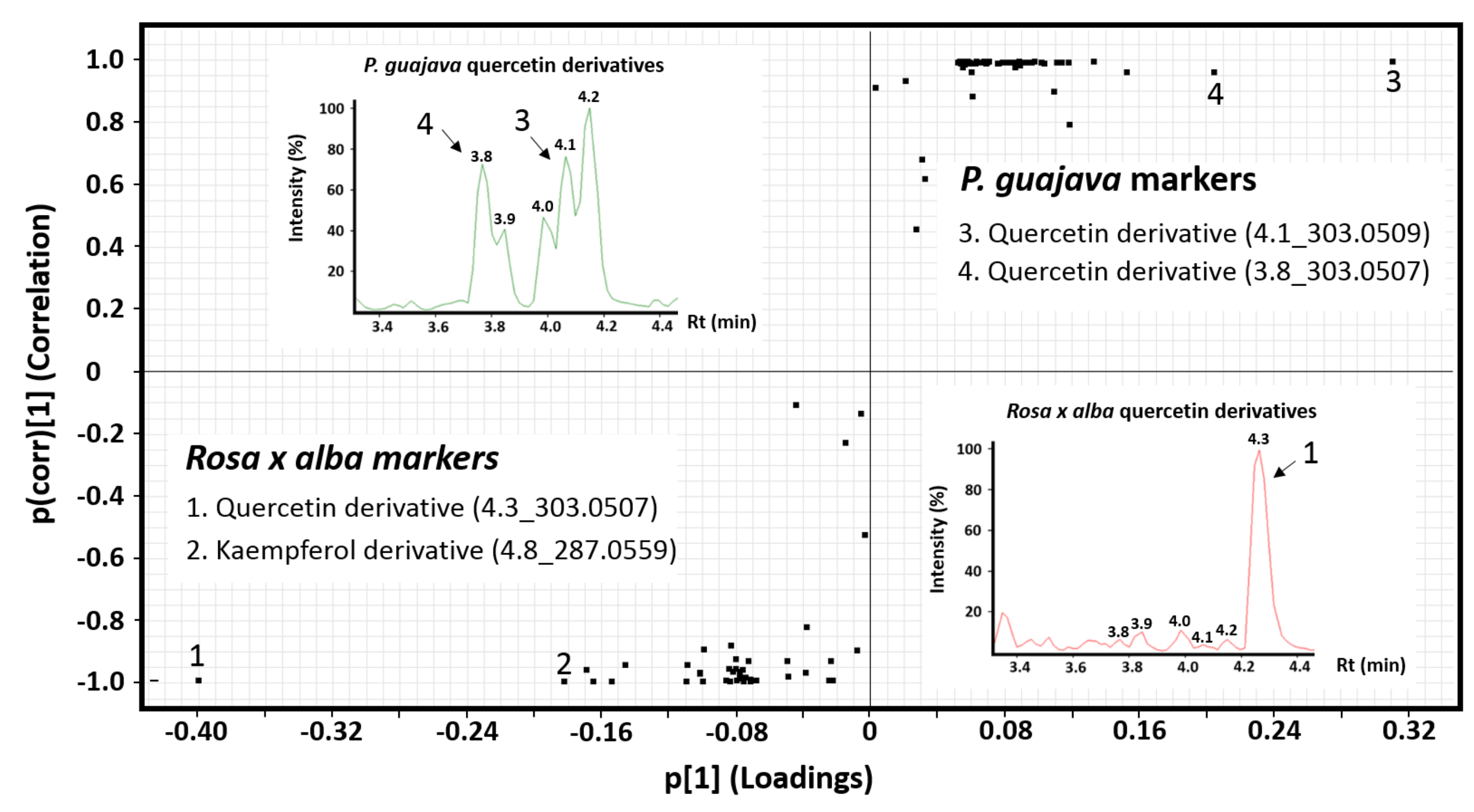




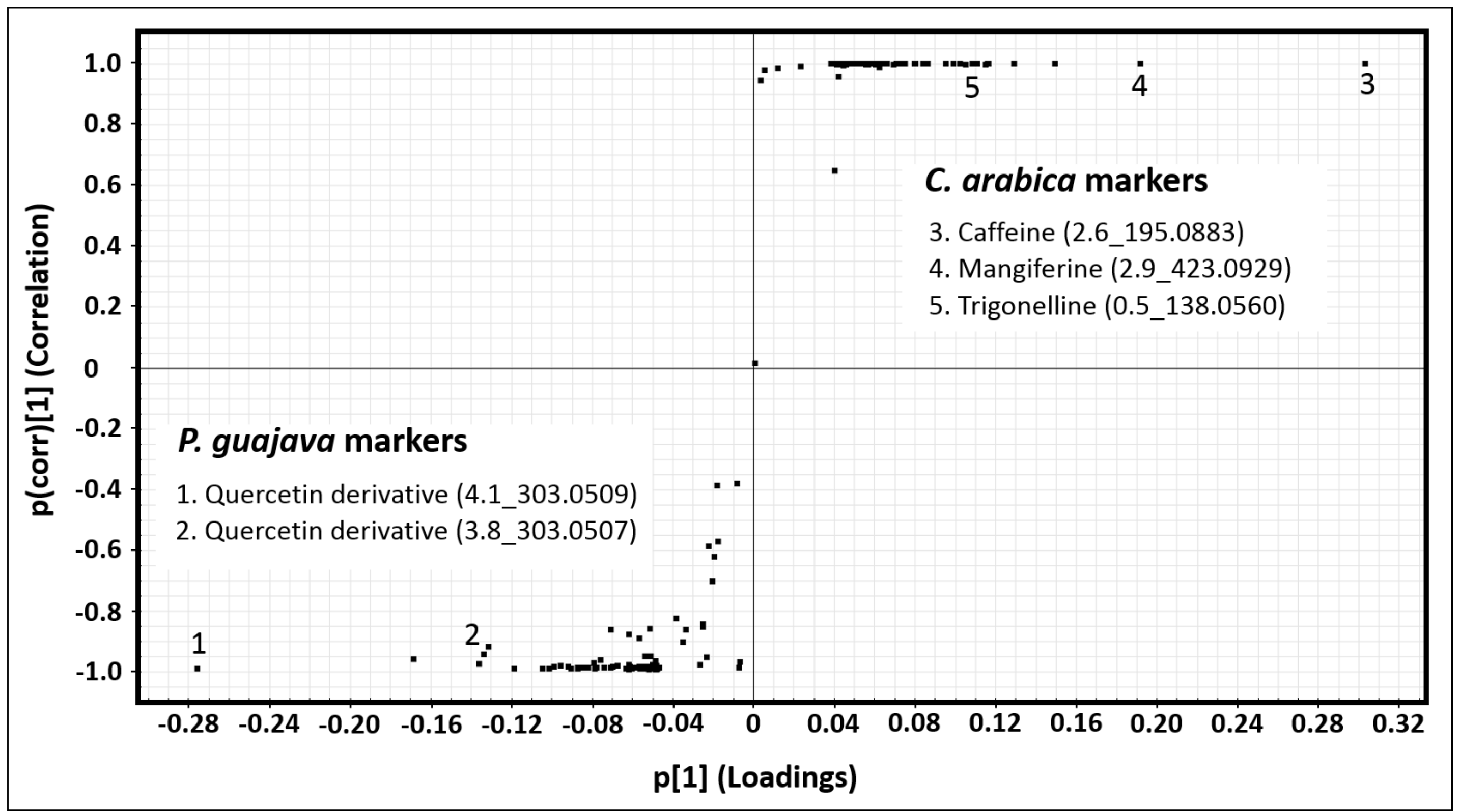




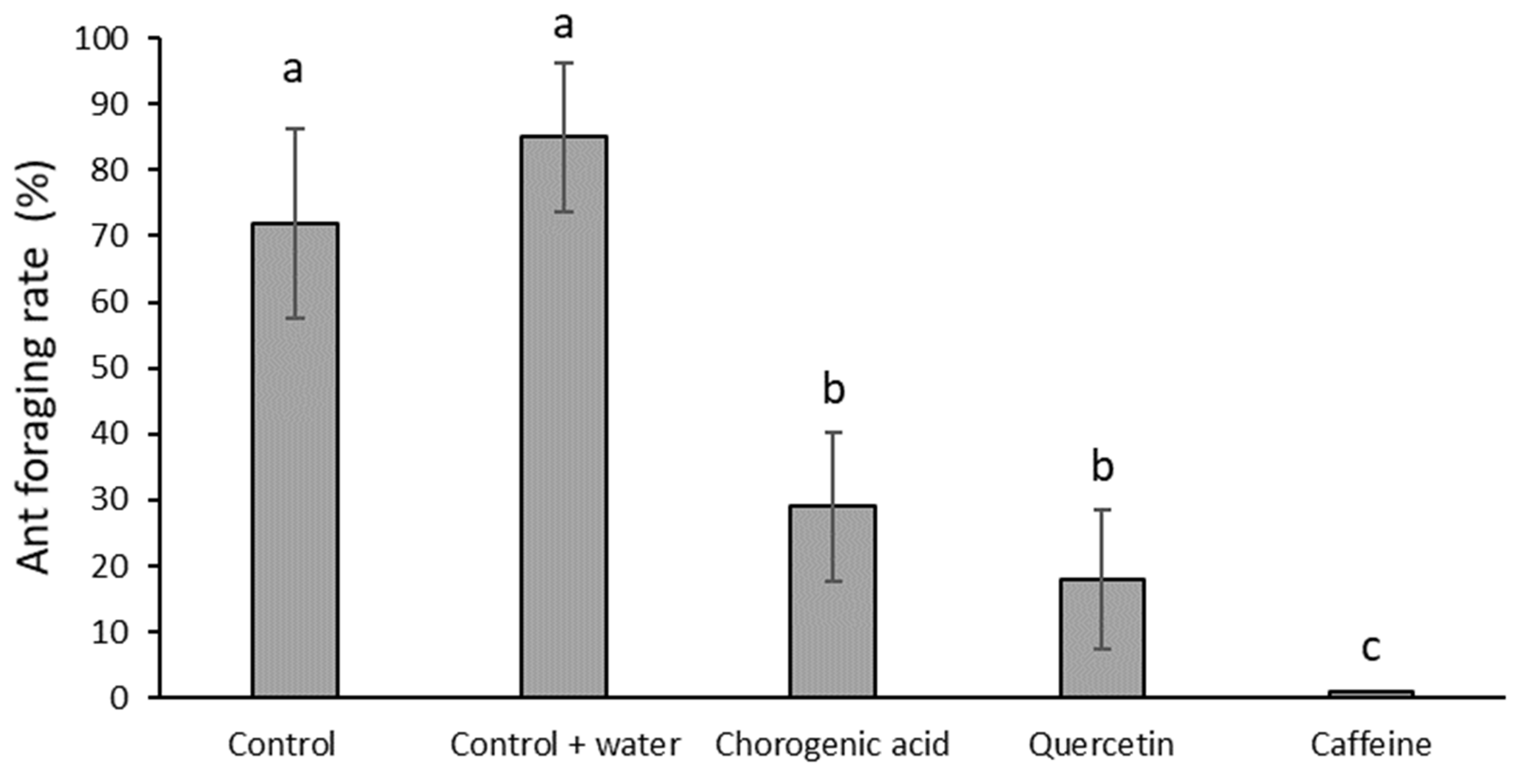




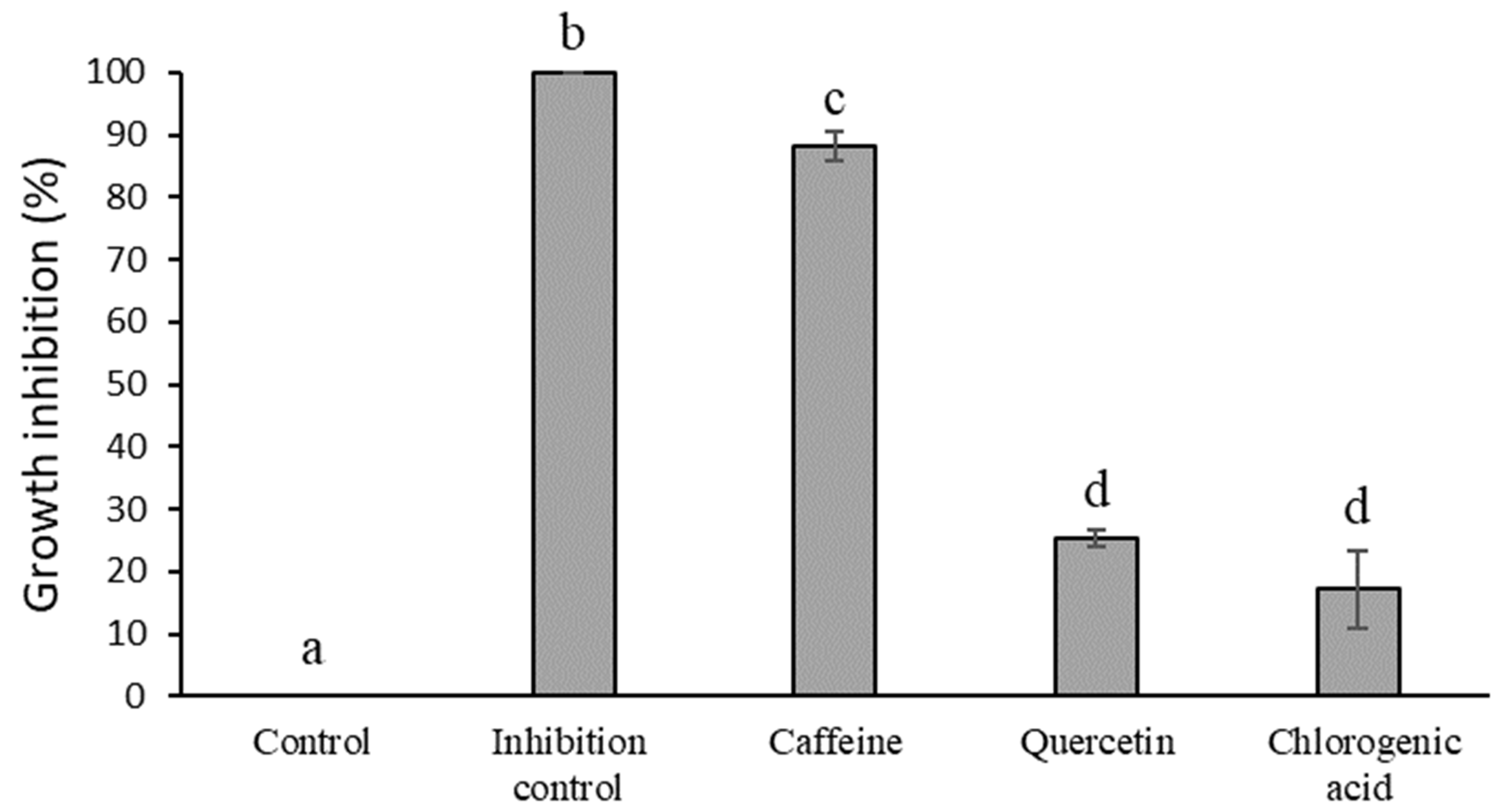




\section{Supplementary material}

2 Supplementary Table 1. Conditions and search compounds using HPLC-MS protocol operated in dynamic MRM (Multiple

3 Reaction Monitoring).

\begin{tabular}{|c|c|c|c|c|c|c|c|}
\hline Compound & $\begin{array}{l}\text { Precursor } \\
\text { ion }\end{array}$ & $\begin{array}{l}\text { Product } \\
\text { ion }\end{array}$ & $\begin{array}{l}\text { Retention } \\
\text { time }\end{array}$ & $\begin{array}{c}\text { Collision } \\
\text { energy }\end{array}$ & Polarity & $\mathbf{R}^{2}$ & $\begin{array}{c}\text { Linearity } \\
\text { range } \\
(\mu \mathrm{M})\end{array}$ \\
\hline Shikimic acid & 173.04 & 93.3 & 1.42 & 10 & Negative & 0.99 & $1-9$ \\
\hline Gallic acid & 168.9 & 125 & 1.5 & 10 & Negative & 0.99 & $1-9$ \\
\hline Protocatechuic acid & 153.02 & 109.03 & 6.28 & 10 & Negative & 0.99 & $1-12$ \\
\hline Gentisic acid & 153.02 & 109.03 & 9.16 & 10 & Negative & 0.99 & $1-12$ \\
\hline 4-hydroxybenzoic acid & 137.02 & 93.03 & 9.4 & 10 & Negative & 0.99 & $1-12$ \\
\hline$(+)$-Catechin & 291.1 & 139.03 & 11.3 & 10 & Positive & 0.99 & $1-9$ \\
\hline Vanillic acid & 169.04 & 151.04 & 12 & 10 & Positive & 0.99 & $1-12$ \\
\hline Scopolin & 355.1 & 193 & 12.2 & 20 & Positive & 0.99 & $1-9$ \\
\hline Chlorogenic acid & 353.08 & 191.05 & 12.3 & 10 & Negative & 0.99 & $1-12$ \\
\hline Caffeic acid & 179 & 135 & 12.5 & 10 & Negative & 0.99 & $1-12$ \\
\hline Procyanidin B2 & 577.14 & 425.09 & 13.58 & 10 & Negative & 0.99 & $1-12$ \\
\hline (-)-Epicatechin & 291.1 & 139.1 & 14.6 & 10 & Positive & 0.99 & $1-12$ \\
\hline Mangiferin & 423.09 & 303.05 & 15.1 & 10 & Positive & 0.99 & $1-12$ \\
\hline Vanillin & 153 & 93 & 15.3 & 10 & Positive & 0.99 & $1-12$ \\
\hline 4-Coumaric acid & 163.05 & 119 & 16.4 & 10 & Negative & 0.99 & $1-12$ \\
\hline Umbelliferone & 163.03 & 107.0495 & 17.3 & 30 & Positive & 0.99 & $1-12$ \\
\hline $\begin{array}{l}\text { Quercetin 3,4-di-O- } \\
\text { glucoside }\end{array}$ & 627.15 & 303.04 & 17.7 & 10 & Positive & 0.99 & $1-9$ \\
\hline Scopoletin & 193.04 & 133.02 & 18.6 & 10 & Positive & 0.99 & $1-12$ \\
\hline 3-Coumaric acid & 165.05 & 147.04 & 18.71 & 10 & Positive & 0.96 & $1-12$ \\
\hline Ferulic acid & 193.1 & 133.9 & 18.8 & 5 & Negative & 0.99 & $1-12$ \\
\hline Sinapic acid & 223.06 & 208.03 & 19.45 & 10 & Negative & 0.99 & $1-12$ \\
\hline Ellagic acid & 301 & 145.02 & 19.9 & 40 & Negative & 0.99 & $1-12$ \\
\hline Myricitrin & 465.1 & 319.04 & 19.9 & 10 & Positive & 0.99 & $1-12$ \\
\hline Rutin & 611.16 & 465.1 & 20.4 & 10 & Positive & 0.99 & $1-12$ \\
\hline Quercetin 3-D-galactoside & 465.1 & 303.04 & 20.6 & 10 & Positive & 0.99 & $1-12$ \\
\hline
\end{tabular}


5 Supplementary Table 1 (continuation). Conditions and search compounds using HPLC-MS protocol operated in dynamic 6 MRM (Multiple Reaction Monitoring).

\begin{tabular}{|c|c|c|c|c|c|c|c|}
\hline Compound & $\begin{array}{c}\begin{array}{c}\text { Precursor } \\
\text { ion }\end{array} \\
\end{array}$ & $\begin{array}{c}\text { Product } \\
\text { ion }\end{array}$ & $\begin{array}{c}\text { Retention } \\
\text { time }\end{array}$ & $\begin{array}{c}\text { Collision } \\
\text { energy }\end{array}$ & Polarity & $\mathbf{R}^{2}$ & $\begin{array}{c}\text { Linearity } \\
\text { range } \\
(\mu \mathrm{M}) \\
\end{array}$ \\
\hline $\begin{array}{l}\text { Quercetin 3- } \\
\text { glucoside }\end{array}$ & 465.2 & 303.04 & 20.9 & 10 & Positive & 0.99 & $1-12$ \\
\hline $\begin{array}{l}\text { Luteolin 7-O- } \\
\text { glucoside }\end{array}$ & 449.1 & 287.05 & 21.3 & 10 & Positive & 0.99 & $1-9$ \\
\hline $\begin{array}{l}\text { Kaemperol 3-O- } \\
\text { glucoside }\end{array}$ & 449.1 & 287.05 & 23.3 & 10 & Positive & 0.99 & $1-12$ \\
\hline Quercitrin & 449.01 & 303.05 & 23.31 & 10 & Positive & 0.99 & $1-9$ \\
\hline Myricetin & 317.03 & 179 & 24.1 & 10 & Negative & 0.99 & $1-9$ \\
\hline Hesperidin & 609.18 & 301.07 & 24.18 & 20 & Negative & 0.99 & $1-9$ \\
\hline Rosmarinic acid & 361.09 & 163.04 & 24.51 & 10 & Positive & 0.99 & $1-12$ \\
\hline Phloridzin & 435.13 & 273.07 & 24.82 & 10 & Negative & 0.99 & $1-12$ \\
\hline Trans-resveratrol & 229.08 & 135.04 & 25.9 & 10 & Positive & 0.99 & $1-12$ \\
\hline Trans-Cinnamic acid & 147.01 & 103.05 & 28.7 & 10 & Negative & 0.99 & $1-12$ \\
\hline Cirsimarin & 477.13 & 315.07 & 29.2 & 10 & Positive & 0.99 & $1-9$ \\
\hline Quercetin & 303.05 & 153.1 & 29.4 & 35 & Positive & 0.99 & $1-9$ \\
\hline Luteolin & 287.05 & 153.01 & 29.7 & 30 & Positive & 0.99 & $1-9$ \\
\hline Psoralen & 187.04 & 131.05 & 31.5 & 20 & Positive & 0.99 & $1-9$ \\
\hline Angelicin & 187.04 & 131.05 & 32.3 & 20 & Positive & 0.99 & $1-9$ \\
\hline Naringenin & 271.06 & 151 & 32.5 & 10 & Negative & 0.99 & $1-9$ \\
\hline Apigenin & 271.06 & 153.01 & 33.82 & 30 & Positive & 0.99 & $1-9$ \\
\hline Kaempferol & 287.05 & 153.02 & 34.16 & 40 & Positive & 0.96 & $1-12$ \\
\hline Hesperetin & 303.09 & 177.05 & 34.67 & 20 & Positive & 0.99 & $1-9$ \\
\hline Citropten & 207.06 & 192.04 & 36.02 & 20 & Positive & 0.99 & $1-12$ \\
\hline $\begin{array}{l}\text { Nordihydroguaiaretic } \\
\text { acid }\end{array}$ & 303.16 & 193.12 & 41.78 & 10 & Positive & 0.99 & $1-12$ \\
\hline Chrysin & 255.07 & 153.02 & 42.96 & 40 & Positive & 0.99 & $1-12$ \\
\hline Kaempferide & 301.07 & 258.05 & 43.3 & 20 & Positive & 0.99 & $1-9$ \\
\hline
\end{tabular}


Supplementary Table 2. Tentative chemical identification of chemical markers of P. guajava, Rosa $x$ alba, and C. arabica identified by untargeted Metabolomics approach.

\begin{tabular}{|c|c|c|c|c|c|c|c|c|}
\hline $\begin{array}{c}\text { Sample's } \\
\text { markers }\end{array}$ & $\underset{(\min )}{\mathbf{R t}}$ & $\mathbf{m} / \mathbf{z}$ & Formula & Ion & $\begin{array}{l}\text { Error } \\
\text { (nnm) }\end{array}$ & Candidates & \multicolumn{2}{|c|}{ Fragments } \\
\hline \multirow{2}{*}{ P. guajava } & 3.8 & 303.0507 & $\mathrm{C}_{15} \mathrm{H}_{10} \mathrm{O}_{7}^{+}$ & {$[\mathrm{M}+\mathrm{H}]^{+}$} & 0.7 & Quercetin derivative & 229.0504 & 153.0186 \\
\hline & 4.1 & 303.0509 & $\mathrm{C}_{15} \mathrm{H}_{10} \mathrm{O}_{7}^{+}$ & {$[\mathrm{M}+\mathrm{H}]^{+}$} & 1.3 & Quercetin derivative & 229.0502 & 153.0182 \\
\hline \multirow{2}{*}{ Rosa $x$ alba } & 4.3 & 303.0507 & $\mathrm{C}_{15} \mathrm{H}_{10} \mathrm{O}_{7}^{+}$ & {$[\mathrm{M}+\mathrm{H}]^{+}$} & 0.7 & Quercetin derivative & 229.0503 & 153.0184 \\
\hline & 4.8 & 287.0559 & $\mathrm{C}_{15} \mathrm{H}_{10} \mathrm{O}_{6}^{+}$ & {$[\mathrm{M}+\mathrm{H}]^{+}$} & 1.0 & Kaempferol derivative & 258.0546 & 153.0184 \\
\hline \multirow{3}{*}{ C. arabica } & 0.5 & 138.0551 & $\mathrm{C}_{7} \mathrm{H}_{8} \mathrm{NO}_{2}{ }^{+}$ & {$[\mathrm{M}+\mathrm{H}]^{+}$} & -2.9 & Trigonelline & 94.0647 & 92.0489 \\
\hline & 2.6 & 195.0883 & $\mathrm{C}_{8} \mathrm{H}_{11} \mathrm{~N}_{4} \mathrm{O}_{2}{ }^{+}$ & {$[\mathrm{M}+\mathrm{H}]^{+}$} & 0.5 & Caffeine & 138.0661 & 110.0711 \\
\hline & 2.9 & 423.0929 & $\mathrm{C}_{19} \mathrm{H}_{19} \mathrm{O}_{11}{ }^{+}$ & {$[\mathrm{M}+\mathrm{H}]^{+}$} & 0.5 & Mangiferine & 303.0508 & 273.0402 \\
\hline
\end{tabular}




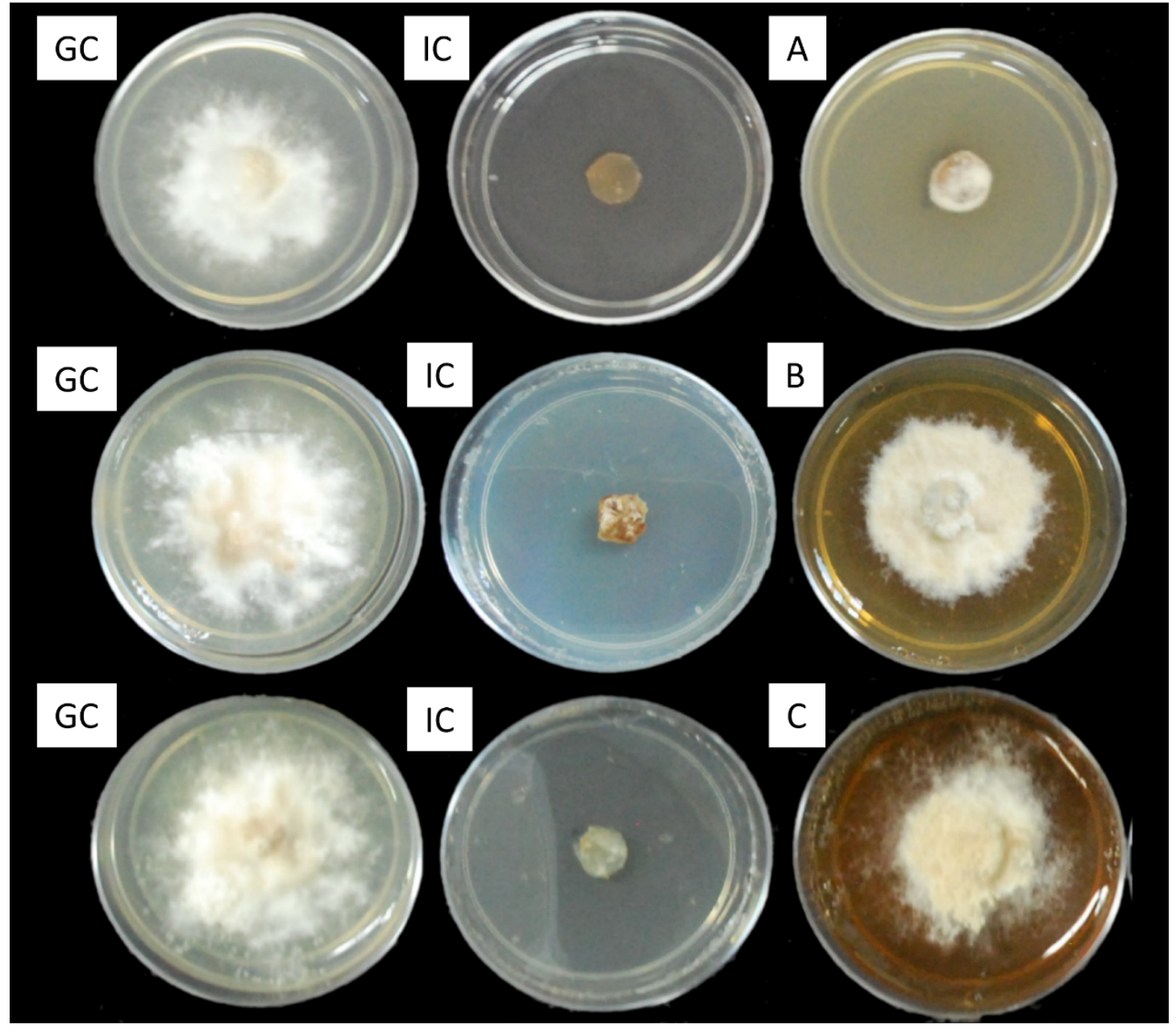


Supplementary Figure 2. Kinetics of the symbiotic fungal growth on different compounds at 0.03, 0.3 and $3 \mathrm{mM}$ [average ( $\mathrm{n}=3$ ) \pm SD] ( $\mathrm{n}=3$ ). PDA was used as growth control, and thiophanate-methyl (MT) as inhibition control.

15

16

17

18

19
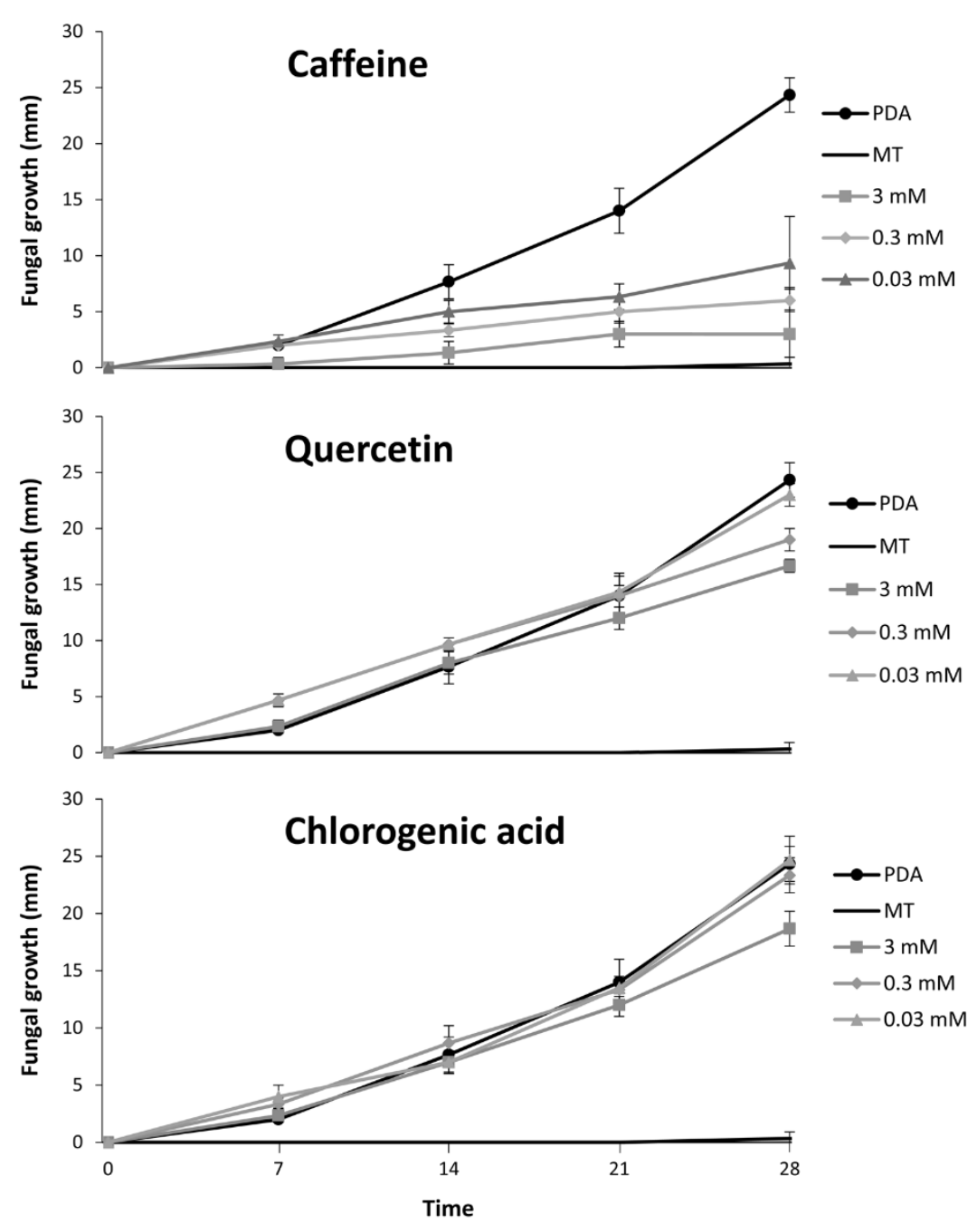
21 Supplementary Figure 3. Identification of the ant fungal symbiont based on morphological characterization: a) Ant nest maintained in laboratory conditions; b) gongylidia (blue22 lactophenol stained) of the mycelium from the ant nest; c) isolated strain of the fungal symbiont on PDA; and d) gongylidia (KOH stained) of the mycelium from the isolated strain 23 grown on PDA.

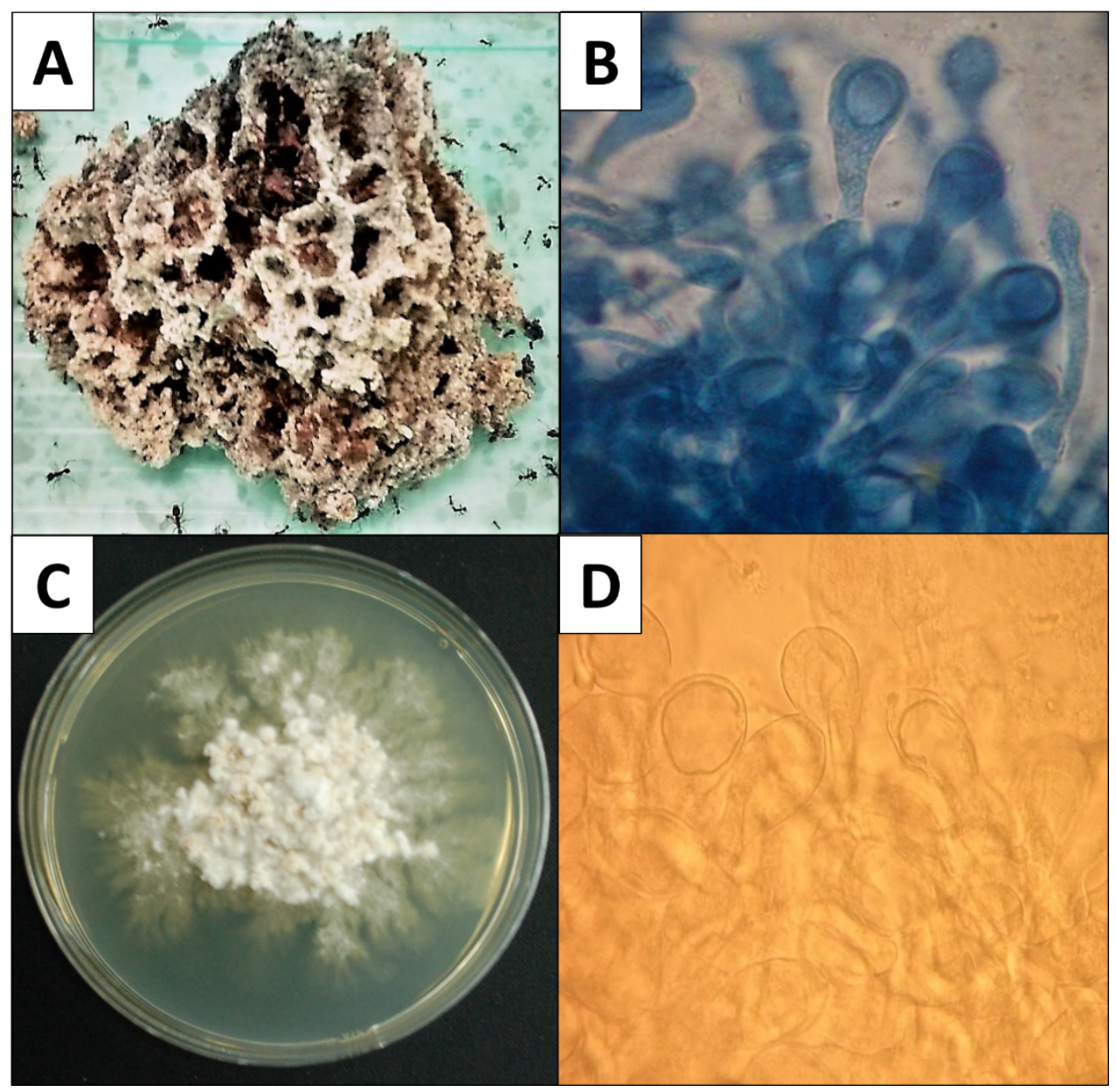

